\title{
The C-terminus of Wheat streak mosaic virus Coat Protein Is Involved in Differential Infection of Wheat and Maize through Host-Specific Long-Distance Transport
}

\author{
Satyanarayana Tatineni and Roy French \\ United States Department of Agriculture-Agricultural Research Service and Department of Plant Pathology, University \\ of Nebraska-Lincoln, Lincoln, NE 68583, U.S.A.
}

Submitted 15 September 2013. Accepted 6 October 2013.

\begin{abstract}
Viral determinants and mechanisms involved in extension of host range of monocot-infecting viruses are poorly understood. Viral coat proteins (CP) serve many functions in almost every aspect of the virus life cycle. The role of the $\mathrm{C}$ terminal region of Wheat streak mosaic virus (WSMV) CP in virus biology was examined by mutating six negatively charged aspartic acid residues at positions 216, 289, 290, 326,333 , and 334 . All of these amino acid residues are dispensable for virion assembly, and aspartic acid residues at positions 216, 333, and 334 are expendable for normal infection of wheat and maize. However, mutants $D_{289} N, D_{289} A$, $\mathrm{D}_{290} \mathrm{~A}, \mathrm{DD}_{289 / 290} \mathrm{NA}$, and $\mathrm{D}_{326} \mathrm{~A}$ exhibited slow cell-to-cell movement in wheat, which resulted in delayed onset of systemic infection, followed by a rapid recovery of genomic RNA accumulation and symptom development. Mutants $D_{289} N, D_{289} A$, and $D_{326} A$ inefficiently infected maize, eliciting milder symptoms, while $\mathrm{D}_{290} \mathrm{~A}$ and $\mathrm{DD}_{289 / 290} \mathrm{NA}$ failed to infect systemically, suggesting that the $\mathrm{C}$-terminus of $\mathrm{CP}$ is involved in differential infection of wheat and maize. Mutation of aspartic acid residues at amino acid positions 289, 290, and 326 severely debilitated virus ingress into the vascular system of maize but not wheat, suggesting that these amino acids facilitate expansion of WSMV host range through host-specific long-distance transport.
\end{abstract}

The ability of plant viruses to systemically infect a wide range of host plants depends on successful interactions between viral and host factors for replication, suppression of host defense mechanisms, and movement (Nelson and Citovsky 2005; Voinnet et al. 1999). Cell-to-cell movement of plant viruses from initially infected cells to adjacent cells occurs through a specialized intercellular connection, the plasmodesmata (Benitez-Alfonso et al. 2010; Lucas et al. 2009; Maule 2008). Infection foci form with continuous cell-to-cell movement until the virus encounters the vascular tissue, followed by loading into phloem-related cells for long-distance transport. Longdistance movement of viruses through phloem-associated cells is more complex, involving the passive transport of viruses along with photosynthates from source to sink tissues and unloading at distal ends through veins, followed by cell-to-cell movement (Carrington et al. 1996; Harries et al. 2010; Hipper

Corresponding author: S. Tatineni; E-mail: satya.tatineni@ars.usda.gov

This article is in the public domain and not copyrightable. It may be freely reprinted with customary crediting of the source. The American Phytopathological Society, 2014. et al. 2013). Successive cycles of cell-to-cell and long-distance translocation of viruses are needed to establish successful systemic infection throughout the plant.

Cell-to-cell movement of plant viruses is an active process mediated by virus-encoded movement proteins (MP) through interactions with host factors (Benitez-Alfonso et al. 2010; Harries and Ding 2011; Waigmann et al. 2004; Wang et al. 1998; Xoconostle-Cazares et al. 2000). Plant viruses encode a diverse range of MP with differences in the mode of virus transport. The tobamovirus $30 \mathrm{~K}$-like MP bind virions or viral ribonucleoprotein complexes and then translocate by increasing the size exclusion limit of plasmodesmata without structural reorganization (Kawakami et al. 2004). In contrast, the MP of members of families Secoviridae, Bromoviridae, and Caulimoviridae facilitate changes to the structural reorganization of plasmodesmata and form tubule-like structures that enable the movement of virus particles or ribonucleoproteins to adjacent cells (BenitezAlfonso et al. 2010; Pouwels et al. 2004). In addition to MP, several viruses encode long-distance transport factors (LTF), which are required exclusively for long-distance transport (Cronin et al. 1995; Ding et al. 1995; Prokhnevsky et al. 2002; Ryabov et al. 1999; Tatineni et al. 2011b).

Plant viruses encode one or more coat proteins (CP) with the exception of umbraviruses, which do not encode any CP. The primary role of $\mathrm{CP}$ is protection of viral genetic information from nuclease degradation by encapsidating viral genomic RNAs or DNAs (Callaway et al. 2001). Additionally, the CP are involved in the translation of viral RNAs (Bol 2005), viral cellto-cell and long-distance transport (Alzhanova et al. 2001; Callaway et al. 2001; Scholthof 2005), vector transmission (Callaway et al. 2001), disease induction (Qu and Morris 2002), and activation of resistance gene-mediated host defenses and suppression of host defense mechanisms (Culver 2002; Qu et al. 2003; Soosaar et al. 2005). Thus, CP are multifunctional, with roles in almost every aspect of the virus life cycle.

Though members of family Potyviridae do not encode a dedicated MP, several potyviral proteins have been implicated in virus intercellular movement with at least one other function in the virus life cycle. Potyviral helper component-proteinase (HC-Pro) (Kasschau et al. 1997; Rojas et al. 1997), CP (Dolja et al. 1994, 1995; Hofius et al. 2007), genome-linked protein (VPg) (Dunoyer et al. 2004), and cylindrical inclusion protein (Carrington et al. 1998; Roberts et al. 1998; Wei et al. 2010) have been implicated in cell-to-cell movement of potyvirid species. Recently, the P3N-PIPO, a small open reading frame (ORF) found within the P3 cistron (Chung et al. 2008), was implicated in cell-to-cell movement of potyvirid species (Choi et al. 2005; Vijayapalani et al. 2012; Wei et al. 2010; Wen and 
Hajimorad 2010). The core domain of Tobacco etch potyvirus (TEV) CP is required for cell-to-cell movement and the $\mathrm{N}$ - and C-terminal regions are required for long-distance transport (Dolja et al. 1994, 1995). So far, the roles of viral proteins in virus movement among members of the Potyviridae family have been studied only for those of the Potyvirus genus.

Wheat streak mosaic virus (WSMV) is an economically important wheat virus in the Great Plains region of the United States with estimated annual yield losses of 2 to $5 \%$ with $100 \%$ losses in localized infections (Brakke 1987; French and Stenger 2004). WSMV is the type species of the genus Tritimovirus within the family Potyviridae (Stenger et al. 1998) with a single-stranded positive-sense genomic RNA of 9,384 nucleotides [excluding the $3^{\prime}$ poly (A) tail] encapsidating in flexuous filamentous 690 - to $700-\mathrm{nm} \times 10$ - to $15-\mathrm{nm}$ virions. The genomic organization of WSMV is similar to members of the aphid-transmitted Potyvirus and mite-transmitted Rymovirus genera of the family Potyviridae, with a single large ORF encoding a polyprotein of approximately $350 \mathrm{kDa}$ (Fig. 1). The polyprotein is processed into 10 mature proteins, analogous to potyviruses, by three virus-encoded proteinases, namely, P1, HC-Pro, and NIa-Pro. However, WSMV and potyviruses differ from each other with regard to the functions of P1 and HC-Pro in the virus life cycle. HC-Pro of WSMV is dispensable for systemic infection of wheat in contrast to the multifunctional HC-Pro of the Potyvirus genus (Anandalakshmi et al. 1998; Atreya and Pirone 1993; Cronin et al. 1995; Kasschau and Carrington 1998; Stenger et al. 2005a). The P1 of WSMV is the suppressor of RNA silencing in contrast to HC-Pro of members of the Potyvirus genus (Kasschau and Carrington 1998; Young et al. 2012). The wheat curl mite (Aceria tosichella Keifer) transmits WSMV in a semipersistent manner (Slykhuis 1955), and HC-Pro has been implicated as a viral determinant for mite transmission (Stenger et al. 2005b, 2006).

The role of WSMV proteins in cell-to-cell and long-distance movement is not known, except that synonymous substitutions in the P3 cistron, which either mutated amino acid residues or introduced stop codons in the overlapping PIPO ORF (Chung et al. 2008), severely affected cell-to-cell movement (Choi et al. 2005). The WSMV CP is 349 amino acid residues long and the N-terminal region is involved in host- and strain-specific LTF in maize (Zea mays L.) inbred line SDp2 (Tatineni et al. 2011b). However, no information is available on the role of the $\mathrm{C}$-terminal region of CP in virus biology. The WSMV CP contains seven aspartic acid (D) residues, the smallest negatively charged amino acid, in the C-terminal 69 amino acid residues (Fig. 1). We studied the role of the C-terminal region of WSMV $\mathrm{CP}$ in virus movement and host specificity by arbitrarily mutating aspartic acid residues at amino acid positions 216, 289, 290, 326, 333, and 334 and examining the ability of these mutants to infect wheat and SDp2 maize. We found that these amino acids are dispensable for virion assembly, but mutation of aspartic acid residues at positions 289, 290, and 326 debilitated long-distance transport in maize but not in wheat. These amino acids facilitate expansion of WSMV host range through host-specific long-distance movement by allowing virus ingress into the vascular system of maize.

\section{RESULTS}

The role of the C-terminal region of WSMV CP in virus biology was examined by mutating negatively charged aspartic acid residues at position $216,289,290,326,333$, or 334 to alanine, and the aspartic acid residue at position 289 was also mutated to asparagine (Fig. 1). Additionally, two dual-substitution mutants were created by substituting aspartic acid residues at positions 289/290 and 333/334 with asparagine/alanine and alanine/alanine, respectively. As a control, a glutamic acid residue, another negatively charged amino acid at position 337, was mutated to alanine (Fig. 1).

\section{Mutation of aspartic acid residues at positions 289, 290, and 326 delayed the onset of systemic symptoms in wheat.}

In vitro-generated RNA transcripts of WSMV with mutation of aspartic acid residues in the $\mathrm{CP}$ were inoculated to wheat $\mathrm{cv}$. Tomahawk seedlings at the single-leaf stage as described by Tatineni and associates (2011a). Inoculated wheat plants were

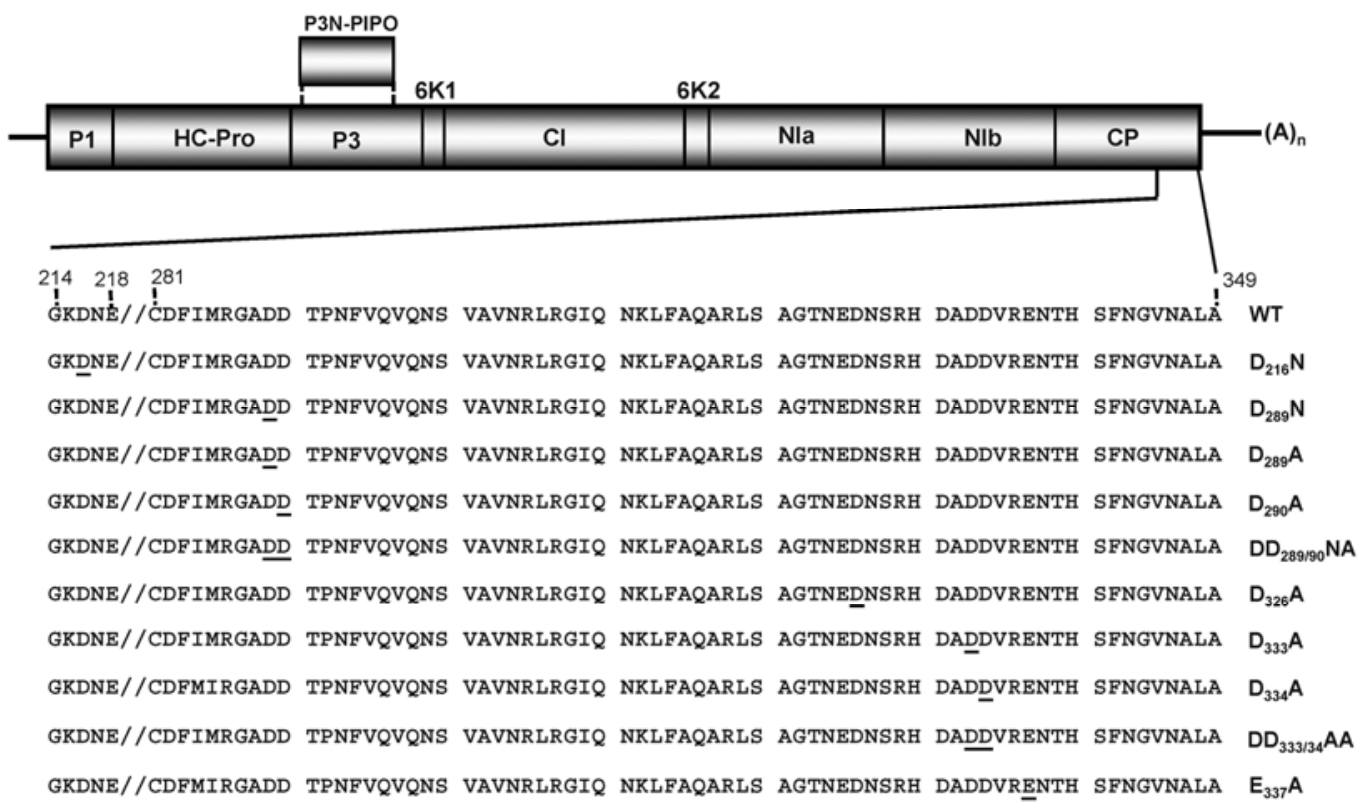

Fig. 1. Genome organization of Wheat streak mosaic virus (WSMV) and mutations introduced at the C-terminal region of coat protein (CP). Locations of proteins encoded by the WSMV genome are indicated and the positions of cleavage sites in the genome are indicated with vertical lines inside the large open reading frame (ORF) encoding for a polyprotein. The P3N-PIPO ORF is indicated with a separate box above the P3 cistron. The C-terminal region of the CP is enlarged below the genomic organization with mutated aspartic acid or glutamic acid residues (underlined). The positions and nature of introduced mutations in the $\mathrm{C}$-terminal region of $\mathrm{CP}$ are indicated at the right. 
incubated in a greenhouse at 20 to $27^{\circ} \mathrm{C}$ and systemic symptoms were observed at $7,9,11$, and 15 days postinoculation (dpi).

At $7 \mathrm{dpi}$, wheat seedlings inoculated with mutants $\mathrm{D}_{216} \mathrm{~A}$, $\mathrm{D}_{333} \mathrm{~A}, \mathrm{D}_{334} \mathrm{~A}$ and $\mathrm{DD}_{333 / 334} \mathrm{AA}$ elicited mild chlorotic streaks and spots and mosaic symptoms in 80 to $94 \%$ of plants, similar to WSMV-Sidney (wild-type) (Table 1; Fig. 2A). At 11 to $15 \mathrm{dpi}$, these mutants infected 94 to $100 \%$ of plants causing severe chlorotic streaks, leaf chlorosis, and mosaic symptoms similar to those of the wild-type virus (Fig. 2A). In contrast, at 7 dpi, mutants $\mathrm{D}_{289} \mathrm{~N}$ and $\mathrm{D}_{290} \mathrm{~A}$ elicited only a few chlorotic streaks and spots in 19 to $28 \%$ of plants, and mutants $\mathrm{D}_{289} \mathrm{~A}$, $\mathrm{DD}_{289 / 290} \mathrm{NA}$, and $\mathrm{D}_{326} \mathrm{~A}$ did not induce visible symptoms (Table 1; Fig. 2A). The latter mutants induced the first visible symptoms of a few chlorotic streaks per leaf in 11 to $22 \%$ of plants at 9 dpi (Table 1). The infection rates of all aspartic acid mutants increased drastically to 87 to $100 \%$ by 11 dpi and elicited severe yellowing of lower leaves due to coalescence of chlorotic streaks and mosaic symptoms similar to the wild-type virus (Table 1; Fig. 2A). By 15 dpi, all aspartic acid mutants elicited symptoms approximately similar to those of the wild-type virus (Fig. 2A). The control mutant $\mathrm{E}_{327} \mathrm{~A}$ induced symptoms similar to those of the wild-type virus with no differences in the onset and severity (Table 1; Fig. 2A). These results indicate that aspartic acid residues at positions 289, 290, and 326 in WSMV $\mathrm{CP}$ are required for efficient systemic infection of wheat. Moreover, nucleotide sequence analysis of the progeny aspartic acid mutants from wheat revealed that all the mutant viruses retained introduced mutations, suggesting that severe symptoms induced by aspartic acid mutants by $15 \mathrm{dpi}$ are not due to reversion of introduced mutations.

\section{Attenuation of symptoms in wheat by aspartic acid mutants is correlated with reduced accumulation of $\mathrm{CP}$ and genomic RNA.}

The above experiments suggested that WSMV with mutation of aspartic acid residues at positions 289, 290 and 326 in the $\mathrm{CP}$ attenuated symptoms during the early stages of infection in wheat (Table 1; Fig. 2A). We next examined accumulation of $\mathrm{CP}$ and genomic RNA in aspartic acid mutant-infected wheat at 9 and $15 \mathrm{dpi}$. At $9 \mathrm{dpi}, 45 \mathrm{kDa} \mathrm{CP}$ and two minor proteins of 31 and $29 \mathrm{kDa}$ accumulated in WSMV-Sidney 81 (wild-type virus)-infected samples (Fig. 2B). The latter two minor proteins were attributed to unspecified in vivo proteolytic cleavage of $\mathrm{CP}$ in wheat leaves due to senescence (Brakke et al. 1990). At 9 dpi, CP accumulated at much reduced levels in mutant $\mathrm{D}_{289} \mathrm{~N}-, \mathrm{D}_{289} \mathrm{~A}-, \mathrm{D}_{290} \mathrm{~A}-, \mathrm{DD}_{289 / 290} \mathrm{NA}-$, or $\mathrm{D}_{326} \mathrm{~A}-$ infected wheat, particularly in the latter two mutants, compared with wild-type virus (Fig. 2B, top panel). Conversely, the $\mathrm{CP}$ accumulated at levels similar to those of the wild-type virus in mutant $\mathrm{D}_{216} \mathrm{~A}-, \mathrm{D}_{333} \mathrm{~A}-, \mathrm{D}_{334} \mathrm{~A}-, \mathrm{DD}_{333 / 334} \mathrm{AA}-$, or $\mathrm{E}_{337} \mathrm{~A}$-infected wheat (Fig. 2B, top panel). At $15 \mathrm{dpi}, \mathrm{CP}$ accumulated in all aspartic acid mutants- and wild-type virusinfected wheat at approximately similar levels (Fig. 2B, bottom panel). CP from mutant-infected plants migrated slightly faster than that from the wild-type virus, due to either size differences between aspartic acid or glutamic acid and alanine residues, or conformational changes due to substituted amino acids, or both. The two truncated $\mathrm{CP}$ bands also migrated slightly faster than the corresponding bands of wild-type virus, suggesting that these truncated $\mathrm{CP}$ comprised the $\mathrm{C}$-terminus of CP (Fig. 2B).

Accumulation of genomic RNAs in aspartic acid mutantinfected wheat was examined by real-time reverse transcription-polymerase chain reaction (PCR) at 9 and $15 \mathrm{dpi}$. The genomic RNA in mutant $\mathrm{D}_{289} \mathrm{~N}-, \mathrm{D}_{289} \mathrm{~A}-, \mathrm{D}_{290} \mathrm{~A}-, \mathrm{DD}_{289 / 290} \mathrm{NA}-$, or $\mathrm{D}_{326} \mathrm{~A}$-infected wheat accumulated at only 1 to $14 \%$ of the wild-type virus at 9 dpi (Table 2). Particularly, the mutants $\mathrm{DD}_{289 / 290} \mathrm{NA}$ and $\mathrm{D}_{326} \mathrm{~A}$ accumulated at much reduced levels of 1 and $3 \%$, respectively, of the wild-type virus. In contrast, viral genomic RNA in mutant $\mathrm{D}_{216} \mathrm{~A}-, \mathrm{D}_{333} \mathrm{~A}-, \mathrm{D}_{334} \mathrm{~A}-$, or $\mathrm{DD}_{333 / 334} \mathrm{AA}$-infected wheat accumulated at moderate levels of 34 to $79 \%$, as compared with wild-type virus (Table 2). At 15 dpi, accumulation of genomic RNAs had generally recovered in all mutant-infected plants. In mutant $\mathrm{D}_{289} \mathrm{~N}$ - or $\mathrm{D}_{289} \mathrm{~A}$ infected wheat, genomic RNAs accumulated at $84 \%$ and $114 \%$, respectively, of the wild-type virus (Table 2). The genomic RNA in mutant $\mathrm{D}_{290} \mathrm{~A}-, \mathrm{DD}_{289 / 290} \mathrm{NA}-$, or $\mathrm{D}_{326} \mathrm{~A}$-infected wheat recovered to a lesser degree, with levels of 46,31 , and $43 \%$

Table 1. Effect of aspartic acid mutations at the C-terminus of the coat protein of Wheat streak mosaic virus (WSMV) on systemic infection of wheat cv. Tomahawk $^{\mathrm{a}}$

\begin{tabular}{|c|c|c|c|c|c|}
\hline Mutant & Experiment & $7 \mathbf{d p i}^{\mathrm{b}}$ & $9 \mathbf{d p i}^{\mathrm{b}}$ & 11 dpi $^{b}$ & 15 dpi $^{b}$ \\
\hline \multirow[t]{2}{*}{ WSMV-Sidney (WT) } & 1 & $12 / 15(80)$ & $14 / 15(93)$ & $15 / 15(100)$ & $15 / 15(100)$ \\
\hline & 2 & $15 / 16(94)$ & $16 / 16(100)$ & $16 / 16(100)$ & $16 / 16(100)$ \\
\hline \multirow[t]{2}{*}{$\mathrm{D}_{216} \mathrm{~A}$} & 1 & $16 / 18(89)$ & $17 / 18(94)$ & $17 / 18(94)$ & $17 / 18(94)$ \\
\hline & 2 & $14 / 15(93)$ & $15 / 15(100)$ & $15 / 15(100)$ & $15 / 15(100)$ \\
\hline \multirow[t]{2}{*}{$\mathrm{D}_{289} \mathrm{~N}$} & 1 & $4 / 18(22)$ & $10 / 18(56)$ & $18 / 18(100)$ & $18 / 18(100)$ \\
\hline & 2 & $3 / 16(19)$ & $7 / 16(44)$ & $16 / 16(100)$ & $16 / 16(100)$ \\
\hline \multirow[t]{2}{*}{$\mathrm{D}_{289} \mathrm{~A}$} & 1 & $0 / 18(0)$ & $4 / 18(22)$ & $16 / 18(89)$ & $18 / 18(100)$ \\
\hline & 2 & $0 / 15(0)$ & $2 / 15(13)$ & $13 / 15(87)$ & $14 / 15(100)$ \\
\hline \multirow[t]{2}{*}{$\mathrm{D}_{290} \mathrm{~A}$} & 1 & $4 / 16(25)$ & $12 / 16(75)$ & $15 / 16(94)$ & $16 / 16(100)$ \\
\hline & 2 & $5 / 18(28)$ & $14 / 18(78)$ & $18 / 18(100)$ & $18 / 18(100)$ \\
\hline \multirow[t]{2}{*}{$\mathrm{DD}_{289 / 290} \mathrm{NA}$} & 1 & $0 / 17(0)$ & $2 / 17(12)$ & $17 / 17(100)$ & $17 / 17(100)$ \\
\hline & 2 & $0 / 16(0)$ & $2 / 16(13)$ & $16 / 16(100)$ & $16 / 16(100)$ \\
\hline \multirow[t]{2}{*}{$\mathrm{D}_{326} \mathrm{~A}$} & 1 & $0 / 18(0)$ & $2 / 18(11)$ & $16 / 18(89)$ & $18 / 18(100)$ \\
\hline & 2 & $0 / 15(0)$ & $2 / 15$ & $14 / 15(93)$ & $15 / 15(100)$ \\
\hline \multirow[t]{2}{*}{$\mathrm{D}_{333} \mathrm{~A}$} & 1 & $14 / 16(88)$ & $14 / 16(88)$ & $16 / 16(100)$ & $16 / 16(100)$ \\
\hline & 2 & $17 / 18(94)$ & $18 / 18(100)$ & $18 / 18(100)$ & $18 / 18(100)$ \\
\hline \multirow[t]{2}{*}{$\mathrm{D}_{334} \mathrm{~A}$} & 1 & $12 / 15(80)$ & $15 / 15(100)$ & $15 / 15(100)$ & $15 / 15(100)$ \\
\hline & 2 & $14 / 16(88)$ & $16 / 16(100)$ & $16 / 16(100)$ & $16 / 16(100)$ \\
\hline \multirow[t]{2}{*}{$\mathrm{DD}_{333 / 334} \mathrm{AA}$} & 1 & $14 / 17(82)$ & $16 / 17(94)$ & $17 / 17(100)$ & $17 / 17(100)$ \\
\hline & 2 & $15 / 18(83)$ & $18 / 18(100)$ & $18 / 18(100)$ & $18 / 18(100)$ \\
\hline \multirow[t]{2}{*}{$\mathrm{E}_{337} \mathrm{~A}$} & 1 & $13 / 16(81)$ & $16 / 16(100)$ & $16 / 16(100)$ & $16 / 16(100)$ \\
\hline & 2 & $17 / 18(94)$ & $18 / 18(100)$ & $18 / 18(100)$ & $18 / 18(100)$ \\
\hline
\end{tabular}

${ }^{a}$ In vitro transcripts prepared from $1 \mu \mathrm{g}$ of linearized cDNA in a $40-\mu 1$ reaction were diluted with an equal volume of $2 \%$ sodium pyrophosphate in the presence of $2 \%$ Celite and were directly inoculated onto wheat seedlings at the single leaf stage. Inoculated wheat plants were incubated in a greenhouse at 20 to $27^{\circ} \mathrm{C}$. Wheat seedlings inoculated with buffer did not develop any symptoms.

${ }^{\mathrm{b}}$ Number of plants infected to the number of plants inoculated at the indicated days postinoculation (dpi); \% of infection is shown in parentheses. 
compared with 6,1 , and $3 \%$ of the wild-type virus at $9 \mathrm{dpi}$, respectively. In contrast, genomic RNAs of mutants $\mathrm{D}_{216} \mathrm{~A}$, $\mathrm{D}_{333} \mathrm{~A}, \mathrm{D}_{334} \mathrm{~A}$, and $\mathrm{DD}_{333 / 334} \mathrm{AA}$ accumulated at 73 to $134 \%$ of wild-type virus (Table 2). These data suggested that mutation of aspartic acid residues at position 289,290 , or 326 in the $\mathrm{CP}$ severely affected the accumulation of virus at $9 \mathrm{dpi}$, followed by a substantial recovery by $15 \mathrm{dpi}$.
The delayed systemic infection in wheat

by aspartic acid mutants is due

to defective cell-to-cell movement.

Recently, we developed green fluorescent protein (GFP) tagged WSMV variants with different cleavage sites at the $3^{\prime}$ end of the GFP cistron, which served as excellent tools to monitor virus spread and distribution in wheat and maize (Tatineni
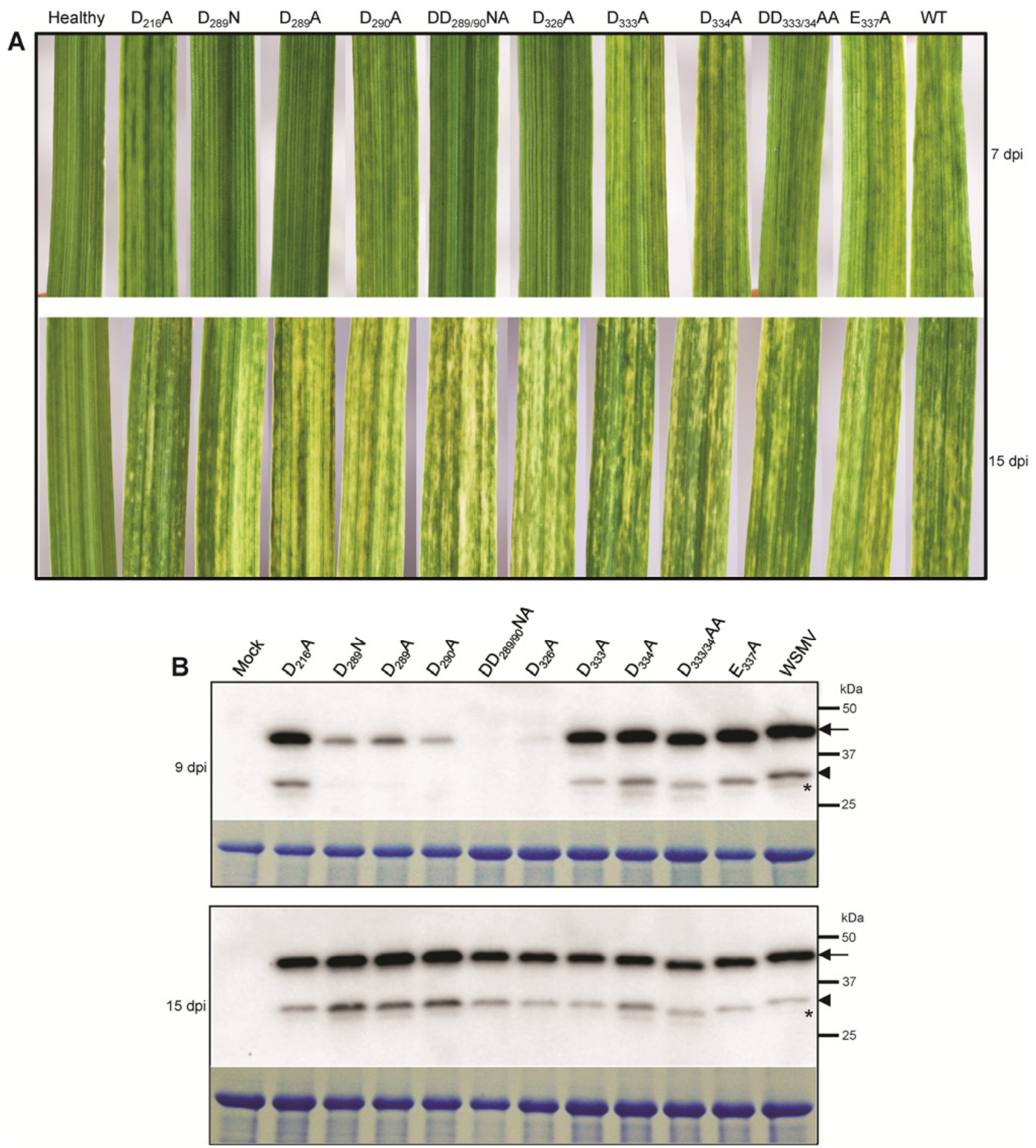

Fig. 2. A, Effect of mutation of aspartic acid residues at the C-terminus of coat protein (CP) of Wheat streak mosaic virus (WSMV) on symptom induction in wheat cv. Tomahawk. In vitro transcripts of cDNA clones with aspartic acid mutations in the CP were inoculated to wheat seedlings at the single-leaf stage, and symptoms were photographed at 7 and 15 days postinoculation (dpi). B, Western blot analysis of total proteins from wheat leaves infected with in vitro transcripts as shown in A at 9 and 15 dpi. Full-length $(45 \mathrm{kDa})$ and truncated 31- and 29-kDa CP that reacted positively with WSMV antibodies are indicated with arrows, arrow heads, and asterisks, respectively. The large subunit of Rubisco protein of wheat in Coomassie Brilliant blue-stained sodium dodecyl sulfate-polyacrylamide gel electrophoresis (SDS-PAGE) was used as a control for the amount of protein loaded per well. The protein size markers used in SDSPAGE are indicated on the right. Note that WSMV with aspartic acid mutations at amino acid position 289, 290, or 326 substantially affected symptom induction and accumulation of $\mathrm{CP}$ in wheat at 7 and 9 dpi, respectively. 
et al. 2011a and b, 2013). The effect of aspartic acid mutations at the C-terminus of the $\mathrm{CP}$ on cell-to-cell and long-distance movement of WSMV was examined by transferring selective mutations into GFP-tagged WSMV, WSMV-S81-GFP-6K1/CI (7aa) (Tatineni et al. 2011a).

In vitro transcripts of GFP-tagged aspartic acid mutants were inoculated to wheat seedlings at the single-leaf stage and the GFP fluorescence was examined in upper fully expanded noninoculated leaves for systemic virus spread under a Zeiss Stereo Discovery V12 fluorescence microscope at 7, 10, 15, and 22 dpi (Fig. 3). At 7 dpi, a large number of GFP foci along the veins covering a majority of the leaf lamina was observed in mutant $\mathrm{D}_{216} \mathrm{~A}-, \mathrm{DD}_{333 / 334} \mathrm{AA}-$, and $\mathrm{E}_{337} \mathrm{~A}$-infected leaves, similar to wild-type virus. In contrast, a moderate number of foci (15 to
30) per leaf in 20 to $30 \%$ of $\mathrm{D}_{289} \mathrm{~N}$-infected leaves and only 1 to 3 foci per leaf in 5 to $10 \%$ of $\mathrm{D}_{290} \mathrm{~A}-, \mathrm{DD}_{289 / 290} \mathrm{NA}-$, or $\mathrm{D}_{326} \mathrm{~A}$-infected leaves were observed (Fig. 3, 7 dpi panel). At $10 \mathrm{dpi}$, GFP fluorescence covered most of the leaf lamina in mutant $\mathrm{D}_{216} \mathrm{~A}-$-, $\mathrm{DD}_{333 / 334} \mathrm{AA}-$, or $\mathrm{E}_{337} \mathrm{~A}$-infected wheat, similar to wild-type virus, suggesting efficient systemic infection by these mutant viruses. However, in mutant $\mathrm{D}_{289} \mathrm{~N}-, \mathrm{D}_{290} \mathrm{~A}-$, $\mathrm{DD}_{289 / 290} \mathrm{NA}$-, or $\mathrm{D}_{326} \mathrm{~A}$-infected plants, 20 to 70 foci per leaf were observed in 60 to $80 \%$ of plants (Fig. 3, 10 dpi panel). At 15 dpi, efficient distribution of GFP fluorescence was observed along the veins of a majority of leaf lamina of mutant $\mathrm{D}_{289} \mathrm{~N}-$, $\mathrm{D}_{290} \mathrm{~A}-, \mathrm{DD}_{289 / 290} \mathrm{NA}$-, or $\mathrm{D}_{326} \mathrm{~A}$-infected plants (Fig. 3, $15 \mathrm{dpi}$ panel). Distribution of GFP fluorescence in all mutant-infected plants was approximately similar to wild-type virus by 22 dpi

Table 2. Quantification of genomic RNAs of wild-type Wheat streak mosaic virus (WSMV) and aspartic acid mutants at the C-terminus of coat protein from systemically infected wheat leaves

\begin{tabular}{|c|c|c|c|c|}
\hline \multirow[b]{2}{*}{ Mutation } & \multicolumn{2}{|c|}{9 days postinoculation (dpi) } & \multicolumn{2}{|c|}{15 dpi } \\
\hline & 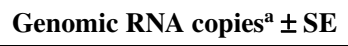 & $\%$ accumulation ${ }^{b}$ & Genomic RNA copies \pm SE & $\%$ accumulation ${ }^{b}$ \\
\hline WSMV-Sidney 81 & $7.49 \times 10^{5} \pm 2.44 \times 10^{4}$ & 100 & $4.00 \times 10^{6} \pm 2.79 \times 10^{5}$ & 100 \\
\hline $\mathrm{D}_{216} \mathrm{~A}$ & $5.15 \times 10^{5} \pm 1.26 \times 10^{4}$ & 69 & $4.68 \times 10^{6} \pm 1.77 \times 10^{5}$ & 117 \\
\hline $\mathrm{D}_{289} \mathrm{~N}$ & $1.02 \times 10^{5} \pm 3.67 \times 10^{3}$ & 14 & $3.35 \times 10^{6} \pm 9.29 \times 10^{4}$ & 84 \\
\hline $\mathrm{D}_{289} \mathrm{~A}$ & $5.77 \times 10^{4} \pm 1.09 \times 10^{4}$ & 8 & $4.54 \times 10^{6} \pm 2.68 \times 10^{5}$ & 114 \\
\hline $\mathrm{D}_{290} \mathrm{~A}$ & $4.16 \times 10^{4} \pm 5.88 \times 10^{2}$ & 6 & $1.84 \times 10^{6} \pm 8.32 \times 10^{4}$ & 46 \\
\hline $\mathrm{DD}_{289 / 290} \mathrm{NA}$ & $7.58 \times 10^{3} \pm 1.08 \times 10^{3}$ & 1 & $1.22 \times 10^{6} \pm 7.14 \times 10^{4}$ & 31 \\
\hline $\mathrm{D}_{326} \mathrm{~A}$ & $2.23 \times 10^{4} \pm 1.05 \times 10^{3}$ & 3 & $1.70 \times 10^{6} \pm 1.22 \times 10^{5}$ & 43 \\
\hline $\mathrm{D}_{333} \mathrm{~A}$ & $2.58 \times 10^{5} \pm 3.81 \times 10^{4}$ & 34 & $2.92 \times 10^{6} \pm 5.38 \times 10^{4}$ & 73 \\
\hline $\mathrm{D}_{334} \mathrm{~A}$ & $5.89 \times 10^{5} \pm 3.66 \times 10^{4}$ & 79 & $4.67 \times 10^{6} \pm 6.29 \times 10^{5}$ & 117 \\
\hline $\mathrm{DD}_{333 / 334} \mathrm{AA}$ & $2.74 \times 10^{5} \pm 1.85 \times 10^{4}$ & 37 & $5.36 \times 10^{6} \pm 1.07 \times 10^{6}$ & 134 \\
\hline Healthy & ND & - & ND & - \\
\hline
\end{tabular}

${ }^{a}$ The number of genomic RNA copies was detected in triplicate samples for each mutant by a real-time polymerase chain reaction method as described by Tatineni and associates (2010). Average number of genomic RNA copies per $2.5 \mathrm{ng}$ of total RNA \pm standard error (SE).

${ }^{\mathrm{b}}$ Percent accumulation over the wild-type virus.

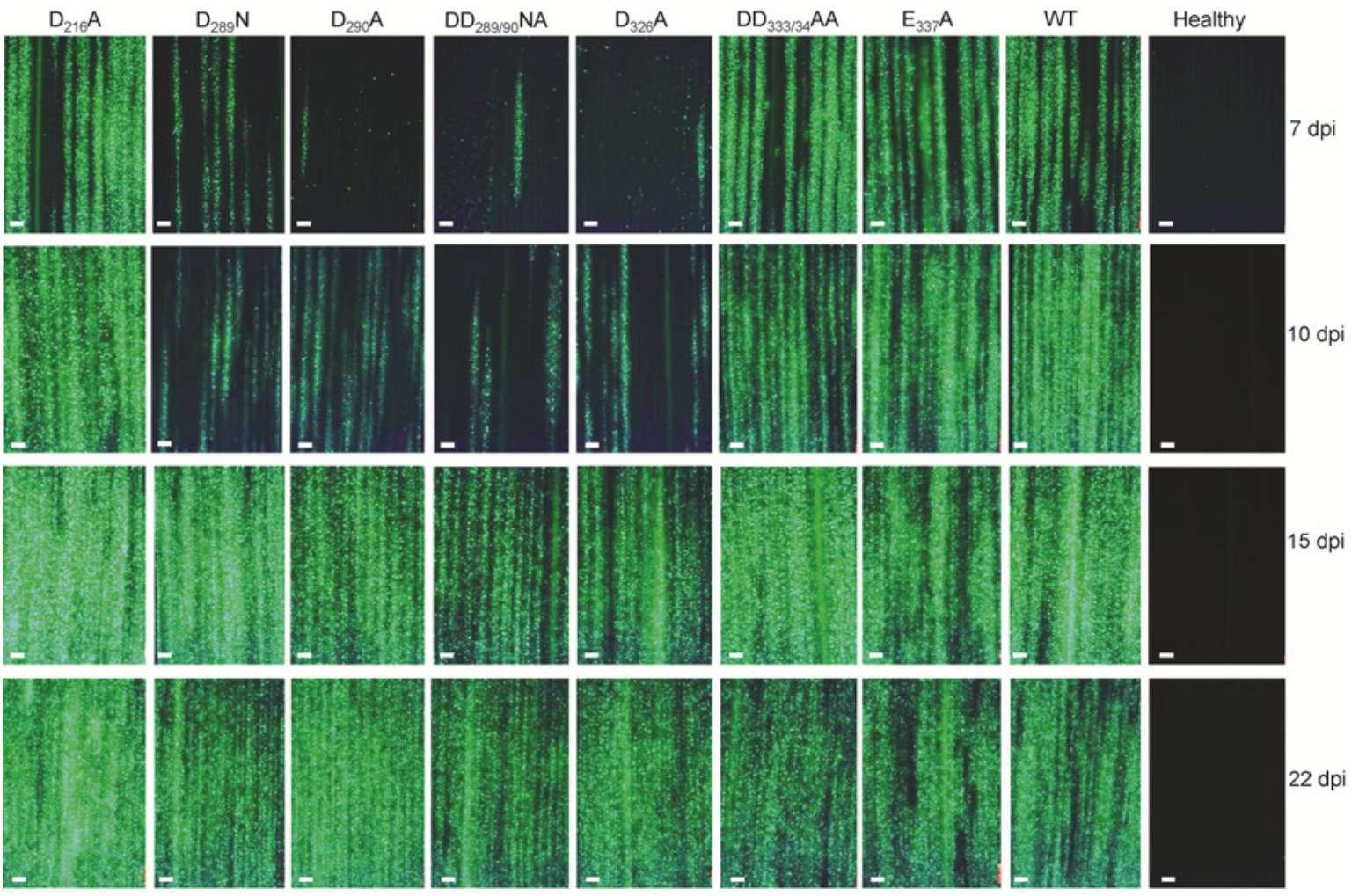

Fig. 3. Wheat streak mosaic virus with aspartic acid mutations in the coat protein (CP) at amino acid positions 289 , 290, and 326 delayed the onset of systemic infection in wheat cv. Tomahawk. In vitro transcripts of green fluorescent protein (GFP)-tagged aspartic acid mutants were inoculated to wheat seedlings at the single-leaf stage, and upper fully expanded leaves were observed under a Zeiss Stereo Discovery V12 fluorescence microscope at 7, 10, 15, and 22 days postinoculation (dpi). Bars represent $500 \mu \mathrm{m}$. Note that a few systemic foci were observed at 7 and 10 dpi in upper fully expanded leaves of wheat infected with GFP-tagged aspartic acid mutants at amino acid position 289, 290, or 326. 
(Fig. 3, 22 dpi panel). These results suggest that the delayed onset of systemic symptoms by mutants $\mathrm{D}_{289} \mathrm{~N}, \mathrm{D}_{290} \mathrm{~A}$, $\mathrm{DD}_{289 / 290} \mathrm{NA}$, and $\mathrm{D}_{326} \mathrm{~A}$ in wheat could be due to defects in one or both cell-to-cell and long-distance transport.

Cell-to-cell movement of aspartic acid mutants was examined by inoculating wheat seedlings at the single-leaf stage with in vitro transcripts of GFP-tagged mutant viruses and observing inoculated leaves, at 4 to $5 \mathrm{dpi}$, under a Zeiss Stereo Discovery V12 fluorescence microscope for foci sizes. Mutants $\mathrm{D}_{216} \mathrm{~A}$ and $\mathrm{E}_{337} \mathrm{~A}$ formed foci similar in size to those of the wild-type virus on inoculated wheat leaves (2.93 to $2.99 \mathrm{~mm}^{2}$ in experiment 1 and 1.91 to $2.15 \mathrm{~mm}^{2}$ in experiment 2) (Table 3 ), suggesting that these amino acids do not affect CP function when exchanged with alanine residues and thus are compatible for cell-to-cell movement. Mutant $\mathrm{DD}_{333 / 334} \mathrm{AA}$ formed local foci of $2.06 \mathrm{~mm}^{2}$ in experiment 1 and $1.88 \mathrm{~mm}^{2}$ in experiment 2 that are slightly smaller than the wild-type virus foci of 2.98 and $2.08 \mathrm{~mm}^{2}$, respectively (Table 3 ). In contrast, mutants $\mathrm{D}_{289} \mathrm{~N}, \mathrm{D}_{290} \mathrm{~A}, \mathrm{DD}_{289 / 290} \mathrm{NA}$, and $\mathrm{D}_{326} \mathrm{~A}$ formed substantially smaller foci of 1.09 to $1.66 \mathrm{~mm}^{2}$ (experiment 1) and 0.75 to

Table 3. Infection foci sizes of green fluorescent protein (GFP)-tagged wild-type Wheat streak mosaic virus (WSMV) and coat protein aspartic acid mutants in inoculated leaves of wheat ${ }^{\mathrm{a}}$

\begin{tabular}{lcc}
\hline & \multicolumn{2}{c}{ Foci sizes $^{\mathbf{b}}$} \\
\cline { 2 - 3 } Mutant & Experiment 1 & Expriment 2 \\
\hline WSMV-GFP-6KI/CI(7aa) (wild-type) & $2.98 \pm 0.36$ & $2.08 \pm 0.80$ \\
$\mathrm{D}_{216} \mathrm{~A}$ & $2.99 \pm 0.74$ & $1.91 \pm 0.45$ \\
$\mathrm{D}_{289} \mathrm{~N}$ & $1.66 \pm 0.48$ & $1.27 \pm 0.44$ \\
$\mathrm{D}_{290} \mathrm{~A}$ & $1.44 \pm 0.42$ & $1.18 \pm 0.47$ \\
$\mathrm{DD}_{289 / 290} \mathrm{NA}$ & $1.09 \pm 0.34$ & $0.75 \pm 0.26$ \\
$\mathrm{D}_{326} \mathrm{~A}$ & $1.26 \pm 0.38$ & $1.05 \pm 0.35$ \\
$\mathrm{DD}_{333 / 334} \mathrm{AA}$ & $2.06 \pm 0.38$ & $1.88 \pm 0.59$ \\
$\mathrm{E}_{337} \mathrm{~A}$ & $2.93 \pm 0.39$ & $2.15 \pm 0.66$ \\
\hline
\end{tabular}

a The sizes of infection foci were estimated at 5 days postinoculation (dpi) for experiment 1 and at 4 dpi for experiment 2 under a Zeiss Stereo Discovery V12 fluorescence microscope.

${ }^{\mathrm{b}}$ In square millimeters \pm standard deviation. Average foci sizes were estimated from 20 to 30 individual foci.
$1.27 \mathrm{~mm}^{2}$ (experiment 2) compared with $2.98 \mathrm{~mm}$ and 2.08 $\mathrm{mm}^{2}$, respectively, of the wild-type virus (Table 3 ). These results suggested that aspartic acid residues at amino acid positions 289, 290, and 326 are required for efficient cell-to-cell movement; thus, defects in cell-to-cell transport might have contributed to delayed onset of systemic symptoms in wheat.

\section{The C-terminus aspartic acid residues}

\section{of $\mathrm{CP}$ are required for systemic infection of maize.}

Previously, we reported the N-terminal region of WSMV CP as a host- and strain-specific long-distance transport factor for systemic infection of maize inbred line SDp2 (Tatineni et al. 2011b). Here, we examined whether the C-terminal aspartic acid residues of $\mathrm{CP}$ are required for systemic infection of SDp2 maize. In vitro transcripts of wild-type cloned virus infected only $10 \%$ of maize seedlings at 30 dpi compared with $100 \%$ infection with a 1:20 diluted crude sap of infected wheat at 8 to $10 \mathrm{dpi}$, suggesting that virions in crude sap are highly infectious to maize. Hence, SDp2 maize seedlings were mechanically inoculated at the two- to three-leaf stage with crude sap at a 1:10 dilution from 18 dpi wheat leaves infected with in vitro transcripts, and symptom development was observed from 12 dpi onwards.

Mutants $\mathrm{D}_{216} \mathrm{~A}, \mathrm{D}_{333} \mathrm{~A}, \mathrm{D}_{334} \mathrm{~A}$, and $\mathrm{DD}_{333 / 334} \mathrm{AA}$ systemically infected $100 \%$ of maize seedlings by 12 dpi. However, mutants $\mathrm{D}_{289} \mathrm{~N}, \mathrm{D}_{289} \mathrm{~A}, \mathrm{D}_{290} \mathrm{~A}, \mathrm{DD}_{289 / 290} \mathrm{NA}$, and $\mathrm{D}_{326} \mathrm{~A}$ failed to infect maize at 12 dpi (Fig. 4; Table 4). At 18 dpi, maize seedlings inoculated with $\mathrm{D}_{289} \mathrm{~N}, \mathrm{D}_{289} \mathrm{~A}$, and $\mathrm{D}_{326} \mathrm{~A}$ elicited a few chlorotic streaks and spots per leaf in 20 to $56 \%$ of inoculated plants (Table 4). These chlorotic streaks and spots were restricted to smaller areas, sometimes to one half of the leaf (Fig. 4). Such mild symptoms continued even after 30 to 35 dpi, suggesting that aspartic acid residues located at amino acid positions 289 and 326 are required for efficient systemic infection of maize. In contrast, mutants $\mathrm{D}_{290} \mathrm{~A}$ and $\mathrm{DD}_{289 / 290} \mathrm{NA}$ failed to infect maize systemically even at 35 to $45 \mathrm{dpi}$, suggesting that the aspartic acid residue at position 290 is critical for systemic infection of maize. The wild-type virus and $\mathrm{E}_{337} \mathrm{~A}$ infected $100 \%$ of inoculated maize seedlings at 12 dpi (Table 4; Fig. 4).
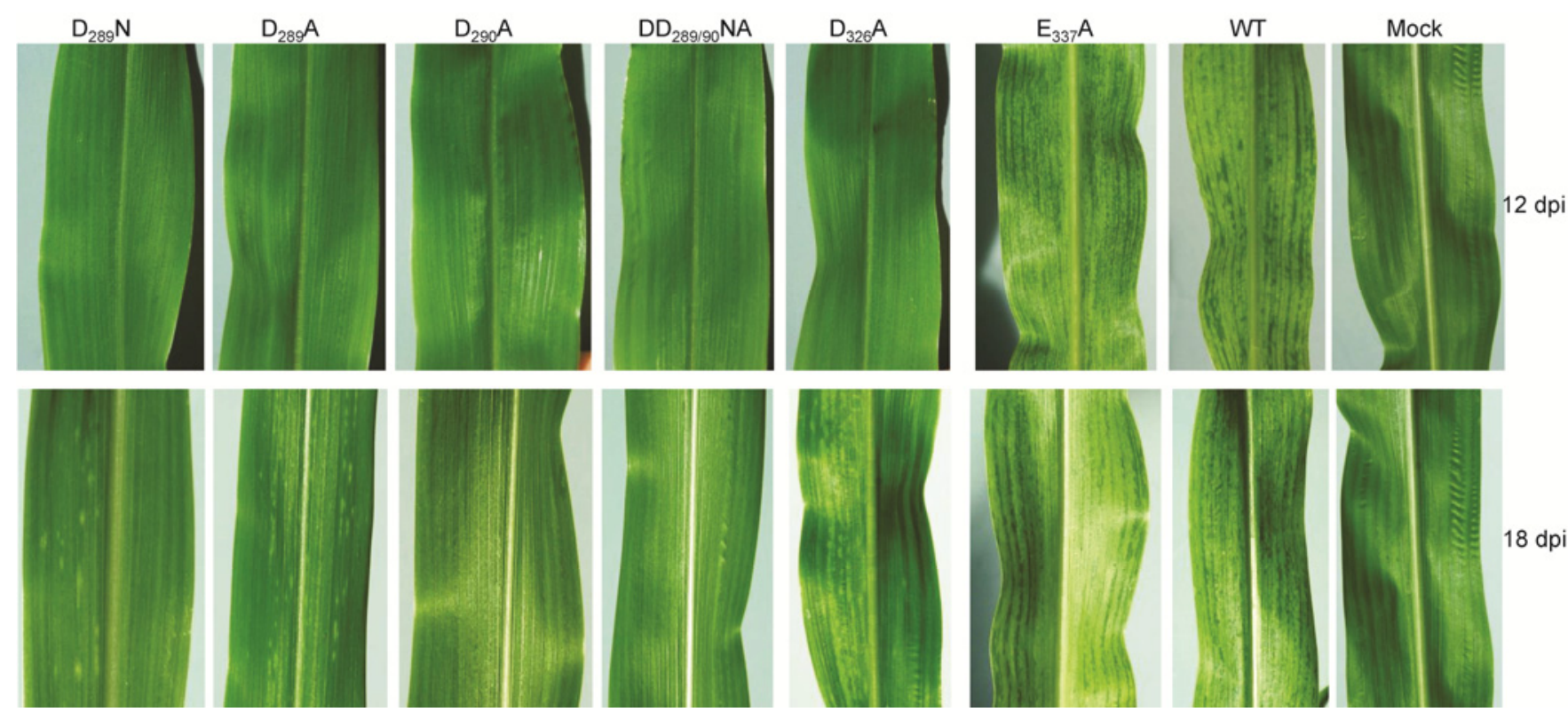

Fig. 4. Aspartic acid residues at positions 289, 290, and 326 in the coat protein of Wheat streak mosaic virus are required for systemic infection of maize (Zea mays L.) inbred line SDp2. Maize seedlings at the two to three-leaf stage were mechanically inoculated with 1:10 diluted crude sap of systemically infected wheat leaves at 18 days postinoculation (dpi). Inoculated plants were incubated in a growth chamber at $24^{\circ} \mathrm{C}$ maximum and $20^{\circ} \mathrm{C}$ minimum temperature with a 14-h photoperiod. Note that mutants $\mathrm{D}_{290} \mathrm{~A}$ and $\mathrm{DD}_{289 / 290} \mathrm{NA}$ failed to infect maize, while mutants $\mathrm{D}_{289} \mathrm{~N}, \mathrm{D}_{289} \mathrm{~A}$ and $\mathrm{D}_{326} \mathrm{~A}$ induced mild chlorotic spots and streaks, and $\mathrm{E}_{337} \mathrm{~A}$ and wild-type (WT) virus efficiently infected at $12 \mathrm{dpi}$. 
Aspartic acid residues at positions 289, 290, and 326 are required for virus ingress into maize vascular system.

The inability of mutants $\mathrm{D}_{289} \mathrm{~N}, \mathrm{D}_{289} \mathrm{~A}, \mathrm{D}_{290} \mathrm{~A}, \mathrm{DD}_{289 / 290} \mathrm{NA}$, and $\mathrm{D}_{326} \mathrm{~A}$ to systemically infect $\mathrm{SDp} 2$ maize at $12 \mathrm{dpi}$ prompted us to monitor the movement of GFP-tagged mutant viruses in inoculated and upper noninoculated leaves of maize. Crude sap diluted 1:10 (wt/vol) from 18-dpi infected wheat leaves was used to mechanically inoculate two sets of SDp2 seedlings. One set of inoculated plants was used to examine the size of local foci at $7 \mathrm{dpi}$, and the other set of plants was used to follow the development of systemic infection.

In two independent experiments, mutants $\mathrm{D}_{216} \mathrm{~A}, \mathrm{DD}_{333 / 334} \mathrm{AA}$, and $\mathrm{E}_{337} \mathrm{~A}$ formed local foci and systemically infected maize seedlings similar to wild-type virus (Table 5; Fig. 5A). However, mutants $\mathrm{D}_{289} \mathrm{~N}, \mathrm{D}_{290} \mathrm{~A}, \mathrm{DD}_{289 / 290} \mathrm{NA}$, and $\mathrm{D}_{326} \mathrm{~A}$ formed smaller foci of 0.44 to $0.99 \mathrm{~mm}^{2}$, compared with foci of 1.15 to $1.80 \mathrm{~mm}^{2}$ formed by the wild-type virus (Table 5), and failed to form systemic foci in upper noninoculated leaves at 15 dpi (Fig. 5A). The smallest local foci were observed with mutant $\mathrm{D}_{326} \mathrm{~A}$ with 0.44 to $0.49 \mathrm{~mm}^{2}$, followed by $\mathrm{DD}_{289 / 290} \mathrm{NA}, \mathrm{D}_{290} \mathrm{~A}$, and $\mathrm{D}_{289} \mathrm{~N}$ with 0.51 to $0.53,0.68$ to 0.76 , and 0.81 to $0.99 \mathrm{~mm}^{2}$, respectively (Table 5). Mutants $\mathrm{D}_{289} \mathrm{~N}$ and $\mathrm{D}_{326} \mathrm{~A}$ infected 10 to $20 \%$ of SDp2 seedlings with a few systemic foci per leaf at 21 to $30 \mathrm{dpi}$ (Fig. 5A). However, mutants $\mathrm{D}_{290} \mathrm{~A}$ and $\mathrm{DD}_{289 / 290} \mathrm{NA}$ failed to elicit detectable systemic foci in upper noninoculated leaves, even at $40 \mathrm{dpi}$, further confirming that the aspartic acid residue at position 290 in the CP is critical for loading or unloading the virus into or out of the vascular system of maize or for both of these functions.

The role of aspartic acid residues at positions 289, 290, and 326 in virus entry into the vascular system of maize was examined by inoculating the upper half of the third leaf of 10 to 15 SDp2 maize seedlings with 1:10-diluted crude sap of the respective GFP-tagged mutant virus-infected wheat leaves. The upper halves of inoculated leaves were observed for the development of local infection foci and the lower noninoculated halves were observed for the presence of virus in the veins at 30 dpi. The sizes of local infection foci in $\mathrm{D}_{289} \mathrm{~N}, \mathrm{D}_{290} \mathrm{~A}$, $\mathrm{DD}_{289 / 290} \mathrm{NA}$, and $\mathrm{D}_{326} \mathrm{~A}$ inoculated areas of maize leaves increased with time and coalesced at $30 \mathrm{dpi}$ (Fig. 5B), suggesting that these mutants were competent in cell-to-cell movement, although at reduced levels compared with wild-type virus. GFP fluorescence was found in the veins of lower noninoculated areas of the wild-type virus- and mutant $\mathrm{DD}_{333 / 334} \mathrm{AA}$-inoculated leaves but not in $\mathrm{D}_{290} \mathrm{~A}$ - or $\mathrm{DD}_{289 / 290} \mathrm{NA}$-inoculated maize leaves at 30 dpi (Fig. 5B). GFP fluorescence was not observed in the veins, even though infection foci developed next to the veins in mutant $\mathrm{D}_{290} \mathrm{~A}$ - or $\mathrm{DD}_{289 / 290} \mathrm{NA}$-inoculated leaves of maize. In contrast, weak GFP fluorescence was observed in the veins next to a few infection foci in $10 \%$ of mutant $\mathrm{D}_{289} \mathrm{~A}$ or $\mathrm{D}_{326} \mathrm{~A}$-inoculated leaves at $30 \mathrm{dpi}$ (Fig. $5 \mathrm{~B}$ ), which is consistent with weak and delayed systemic infection by these mutants in maize. These data demonstrated that aspartic acid residues at positions 289, 290, and 326 are required for virus ingress into the vascular system of maize in order to extend the host range of WSMV.

\section{WSMV CP aspartic acid mutants are competent to form virions.}

Point mutations in viral $\mathrm{CP}$ may affect virion formation as reported for several plant viruses (Dawson et al. 1988; Dolja et al. 1994, 1995; Park et al. 2012; Rao and Grantham 1996). The ability to form virions by aspartic acid mutants was examined by partially purifying virions from systemically infected wheat leaves at $18 \mathrm{dpi}$, as described by Tatineni and associates (2011b). A large number of flexuous filamentous virus particles were observed in partially purified virus preparations of all aspartic acid mutants, and no obvious morphological differences were observed between the mutants and wild-type virions (Fig. 6A). Western blot analysis of partially purified virions from systemically infected wheat leaves further revealed that aspartic acid mutants accumulated virions at approximately the same amounts as those of the wild-type virus at $18 \mathrm{dpi}$ (Fig. $6 \mathrm{~B})$. These data suggested that mutation of aspartic acid residues at position 289, 290, 326, 333, or 334 in the CP did not significantly affect WSMV virion formation. However, we cannot

Table 5. Infection foci sizes of green fluorescent protein-tagged Wheat streak mosaic virus coat protein aspartic acid mutants in inoculated leaves of maize inbred line SDp2 ${ }^{\mathrm{a}}$

\begin{tabular}{lcc}
\hline & \multicolumn{2}{c}{ Foci sizes $^{\mathbf{b}}$} \\
\cline { 2 - 3 } Mutant & Experiment 1 & Experiment 2 \\
\hline WSMV-GFP-6KI/CI(7aa) & $1.80 \pm 0.43$ & $1.15 \pm 0.39$ \\
$\mathrm{D}_{216} \mathrm{~A}$ & $1.72 \pm 0.34$ & $1.32 \pm 0.44$ \\
$\mathrm{D}_{289} \mathrm{~N}$ & $0.99 \pm 0.23$ & $0.81 \pm 0.24$ \\
$\mathrm{D}_{290} \mathrm{~A}$ & $0.68 \pm 0.16$ & $0.76 \pm 0.25$ \\
$\mathrm{DD}_{289 / 290} \mathrm{NA}$ & $0.51 \pm 0.17$ & $0.53 \pm 0.29$ \\
$\mathrm{D}_{326} \mathrm{~A}$ & $0.49 \pm 0.14$ & $0.44 \pm 0.13$ \\
$\mathrm{DD}_{333 / 334} \mathrm{AA}$ & $1.98 \pm 0.51$ & $1.04 \pm 0.24$ \\
$\mathrm{E}_{337} \mathrm{~A}$ & $1.81 \pm 0.47$ & $1.09 \pm 0.35$ \\
\hline
\end{tabular}

${ }^{\text {a }}$ Maize inbred line SDp2 seedlings were inoculated at the two-leaf stage with a 1:10 dilution of crude extracts prepared from 18-days postinoculation (dpi) infected wheat leaves. Inoculated SDp2 seedlings were incubated in a growth chamber at $24^{\circ} \mathrm{C}$ maximum and $20^{\circ} \mathrm{C}$ minimum temperatures with $14 \mathrm{~h}$ of light. Average sizes of foci estimated from 20 to 25 individual foci.

${ }^{\mathrm{b}}$ In square millimeters \pm standard deviation at $7 \mathrm{dpi}$.

c Wild-type virus.

Table 4. Effect of Wheat streak mosaic virus (WSMV) coat protein aspartic acid mutants on systemic infection of maize inbred line SDp2a

\begin{tabular}{|c|c|c|c|c|}
\hline \multirow[b]{2}{*}{ Mutant } & \multicolumn{2}{|c|}{ Experiment $1^{b}$} & \multicolumn{2}{|c|}{ Experiment $2^{b}$} \\
\hline & 12 dpi & 18 dpi & 12 dpi & 18 dpi \\
\hline WSMV-Sidney (wild-type virus) & $6 / 6$ & $6 / 6$ & $7 / 7$ & $7 / 7$ \\
\hline $\mathrm{D}_{216} \mathrm{~A}$ & $7 / 7$ & $7 / 7$ & $8 / 8$ & $8 / 8$ \\
\hline $\mathrm{D}_{289} \mathrm{~N}$ & $0 / 8$ & $3 / 8$ & $0 / 5$ & $1 / 5$ \\
\hline $\mathrm{D}_{289} \mathrm{~A}$ & $0 / 8$ & $3 / 8$ & $1 / 4$ & $2 / 4$ \\
\hline $\mathrm{D}_{290} \mathrm{~A}$ & $0 / 7$ & $0 / 7$ & $0 / 8$ & $0 / 8$ \\
\hline $\mathrm{DD}_{289 / 290} \mathrm{NA}$ & $0 / 8$ & $0 / 8$ & $0 / 7$ & $0 / 7$ \\
\hline $\mathrm{D}_{326} \mathrm{~A}$ & $0 / 9$ & $5 / 9$ & $0 / 7$ & $2 / 7$ \\
\hline $\mathrm{D}_{333} \mathrm{~A}$ & $10 / 10$ & $10 / 10$ & $6 / 6$ & $6 / 6$ \\
\hline $\mathrm{D}_{334} \mathrm{~A}$ & $7 / 7$ & $7 / 7$ & $8 / 8$ & $8 / 8$ \\
\hline $\mathrm{DD}_{333 / 334} \mathrm{AA}$ & $7 / 7$ & $7 / 7$ & $7 / 7$ & $7 / 7$ \\
\hline $\mathrm{E}_{337} \mathrm{~A}$ & $7 / 7$ & $7 / 7$ & $6 / 6$ & $6 / 6$ \\
\hline
\end{tabular}

${ }^{\mathrm{a}}$ Inoculum was prepared from 18 days postinoculation (dpi) infected wheat leaves in $20 \mathrm{mM}$ sodium phosphate buffer, $\mathrm{pH} 7.0$, at a 1:10 dilution. Inoculated plants were incubated in a growth chamber at $24^{\circ} \mathrm{C}$ maximum and $20^{\circ} \mathrm{C}$ minimum temperatures with $14 \mathrm{~h}$ of light.

b Number of plants infected to the number of plants inoculated. 
exclude the possibility of mutation of aspartic acid residues might have affected the efficiency of virion formation. Virion assembly assays in wheat can provide information on virion encapsidation if mutant viruses infect similarly to wild-type virus but not from mutants that are inefficiently infected due to defects in cell-to-cell movement but not in virion assembly.

Because aspartic acid mutants differentially affected cell-tocell movement in wheat, it is not possible to determine whether mutation of aspartic acid residues in the $\mathrm{CP}$ might have affected the efficiency of virion assembly in wheat. It is also possible that reduced virion assembly of aspartic acid mutants might have affected cell-to-cell movement in wheat. Previously, we have shown that WSMV replicates weakly and forms virions without cell-to-cell or long-distance movement in agroinfiltrated Nicotiana benthamiana leaves (Tatineni et al. 2011a, 2013). We took advantage of this movement-independent virion assembly assay to examine virion assembly efficiency of selective aspartic acid mutants.

Mutants $\mathrm{D}_{289} \mathrm{~N}, \mathrm{D}_{290} \mathrm{~A}, \mathrm{DD}_{289 / 290} \mathrm{NA}, \mathrm{D}_{326} \mathrm{~A}$, and $\mathrm{DD}_{333 / 334} \mathrm{AA}$ were transferred to pCAM-WSMV-S81-GFP-6K1/CI(7aa)
(Tatineni et al. 2011a), followed by transformation into Agrobacterium tumefaciens EHA105. As a control, arginine at amino acid position 237 in WSMV CP, a conserved amino acid in all flexuous filamentous plant viruses required for virion formation (Dolja et al. 1991, 1994), was mutated to alanine. Agrobacterium suspensions (1.0 optical density at $600 \mathrm{~nm}$ $\left.\left[\mathrm{OD}_{600}\right]\right)$ harboring WSMV-S81-GFP-6K1/CI(7aa) or arginine or aspartic acid mutants were mixed with equal volumes of 1.0 $\mathrm{OD}_{600}$ agrosuspension harboring a binary vector containing Tomato bushy stunt virus p19, a suppressor of RNA silencing (Qu and Morris 2002) and infiltrated into N. benthamiana leaves as described by Tatineni and associates (2012). Partially purified virions were prepared from $7 \mathrm{~g}$ of 9 days-postagroinfiltrated $N$. benthamiana leaves as described by Tatineni and associates (2011b), followed by Western blot using WSMV CP polyclonal antibodies (Fig. 6C). Mutants $\mathrm{D}_{289} \mathrm{~N}, \mathrm{D}_{290} \mathrm{~A}$, $\mathrm{DD}_{289 / 290} \mathrm{NA}, \mathrm{D}_{326} \mathrm{~A}$, and $\mathrm{DD}_{333 / 334} \mathrm{AA}$ encapsidated virions at approximately similar or higher levels than that of the wildtype virus, and the assembly-null mutant $\mathrm{R}_{237} \mathrm{~A}$ failed to form detectable virions (Fig. 6C). These results demonstrated that

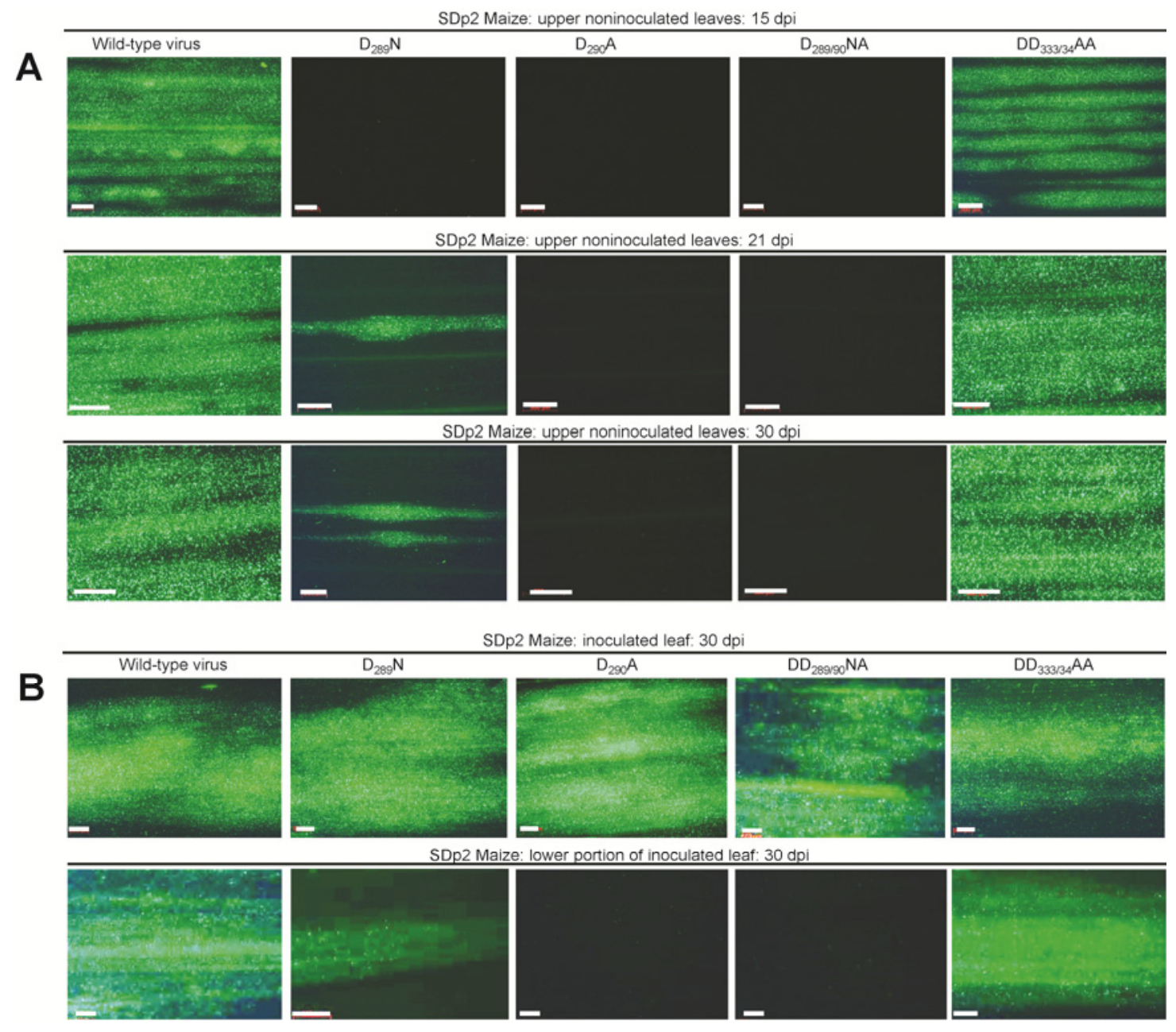

Fig. 5. A, Green fluorescent pretein (GFP)-tagged Wheat streak mosaic virus (WSMV) with mutation of aspartic acid residues at position 289 , 290 , or 326 in the coat protein (CP) displayed profound defects in systemic transport in SDp2 maize. Fully expanded upper noninoculated leaves were observed under a fluorescence microscope for the presence of GFP fluorescence at 15, 21, and 30 days postinoculation (dpi). Note that mutant $\mathrm{D}_{289} \mathrm{~A}$ failed to induce systemic foci at 15 dpi and produced very few foci per leaf at 21 and $30 \mathrm{dpi}$; similar infection foci were induced by mutant $\mathrm{D}_{326} \mathrm{~A}$ (not shown in picture). Mutants $\mathrm{D}_{290} \mathrm{~A}$ and $\mathrm{DD}_{289 / 290} \mathrm{NA}$ failed to infect SDp2 maize systemically, even at 30 dpi. Wild-type virus and mutant $\mathrm{DD}_{333 / 334} \mathrm{AA}$ efficiently infected maize at 15 dpi. B, Aspartic acid residues at positions 289, 290, and 326 in the CP are crucial for WSMV to enter the vascular system for systemic infection in maize. The upper half of the third leaf of maize was mechanically inoculated with crude sap of GFP-tagged aspartic acid mutant-infected wheat leaves. The upper inoculated and lower noninoculated areas of the third leaf were observed under a fluorescence microscope at 30 dpi. Note that mutants $\mathrm{D}_{290} \mathrm{~A}$ and $\mathrm{DD} 289 / 290 \mathrm{NA}$ failed to enter the lower veins of inoculated leaves. Mutant $\mathrm{D}_{289} \mathrm{~N}$ inefficiently entered the vascular system, as weak fluorescence was observed in lower veins of a few noninoculated areas of maize; similar results were observed with mutant $\mathrm{D}_{326} \mathrm{~A}$ (not shown in picture). In contrast, the wild-type virus and mutant $\mathrm{DD}_{333 / 334} \mathrm{AA}$ efficiently entered the vascular system, as strong fluorescence was observed in lower veins of noninoculated areas. Bars represent $500 \mu \mathrm{m}$. 
aspartic acid residues at positions 289, 290, 326, 333, and 334 in CP are dispensable for WSMV virion assembly.

\section{DISCUSSION}

The role of the $\mathrm{C}$-terminal region of $\mathrm{CP}$ in virion formation, disease induction, host specificity, and cell-to-cell and longdistance movement of WSMV was examined by arbitrarily mutating negatively charged aspartic acid residues. The aspartic acid mutants induced two symptom phenotypes in wheat: i) mutants $\mathrm{D}_{216} \mathrm{~A}, \mathrm{D}_{333} \mathrm{~A}, \mathrm{D}_{334} \mathrm{~A}$, and $\mathrm{DD}_{333 / 334} \mathrm{AA}$ do not have a significant effect on symptom phenotype, and ii) mutants $\mathrm{D}_{289} \mathrm{~N}, \mathrm{D}_{289} \mathrm{~A}, \mathrm{D}_{290} \mathrm{~A}, \mathrm{DD}_{289 / 290} \mathrm{NA}$, and $\mathrm{D}_{326} \mathrm{~A}$ induced delayed or mild systemic symptoms during the early stages of infection, followed by severe symptoms similar to those of the wild-type virus. Mutation of aspartic acid at position 289 to asparagine or alanine induced different symptom phenotypes on wheat (Table 1), suggesting that substituted amino acids interacted differently with either host proteins, or other viral proteins, or both. Our data suggest that aspartic acid residues at positions 289, 290, and 326 are required for early events of the infection process in wheat, such as efficient encapsidation
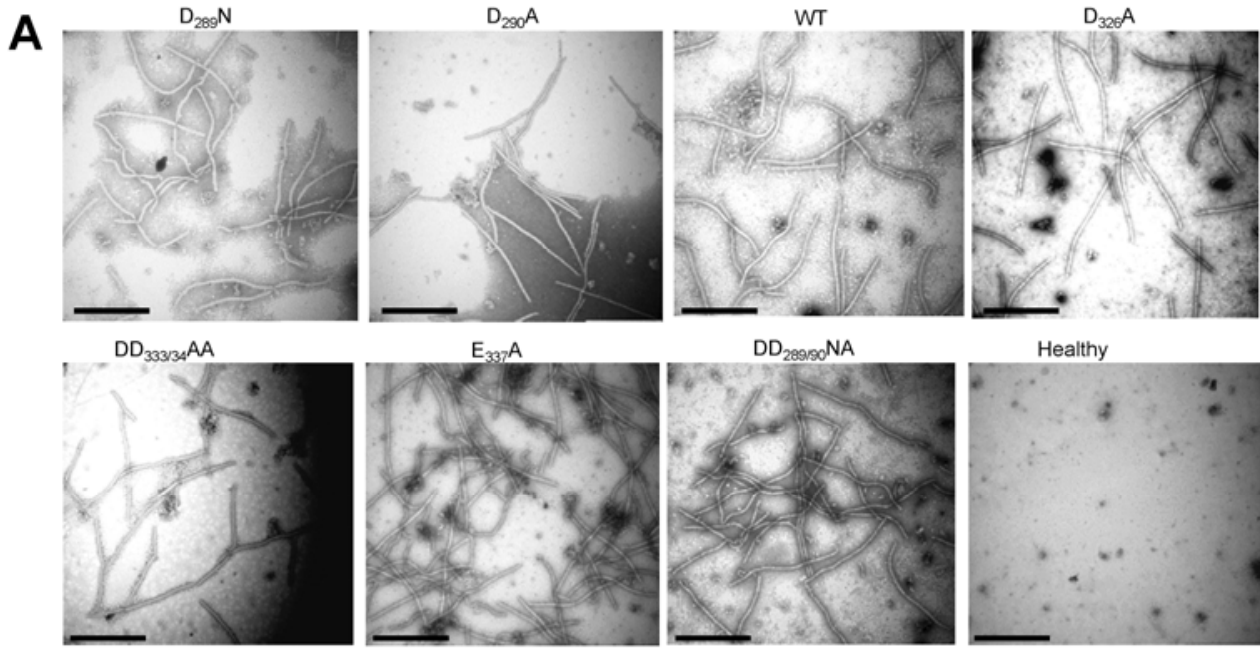

$\mathrm{DD}_{28990 \mathrm{NA}}$
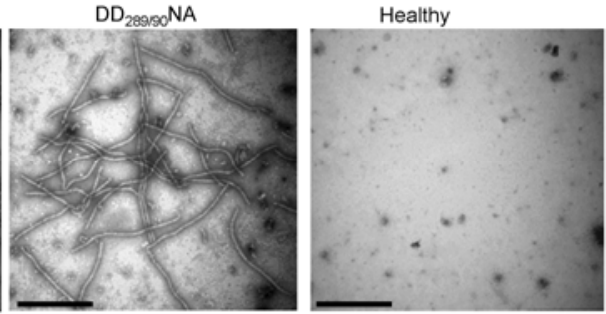

B
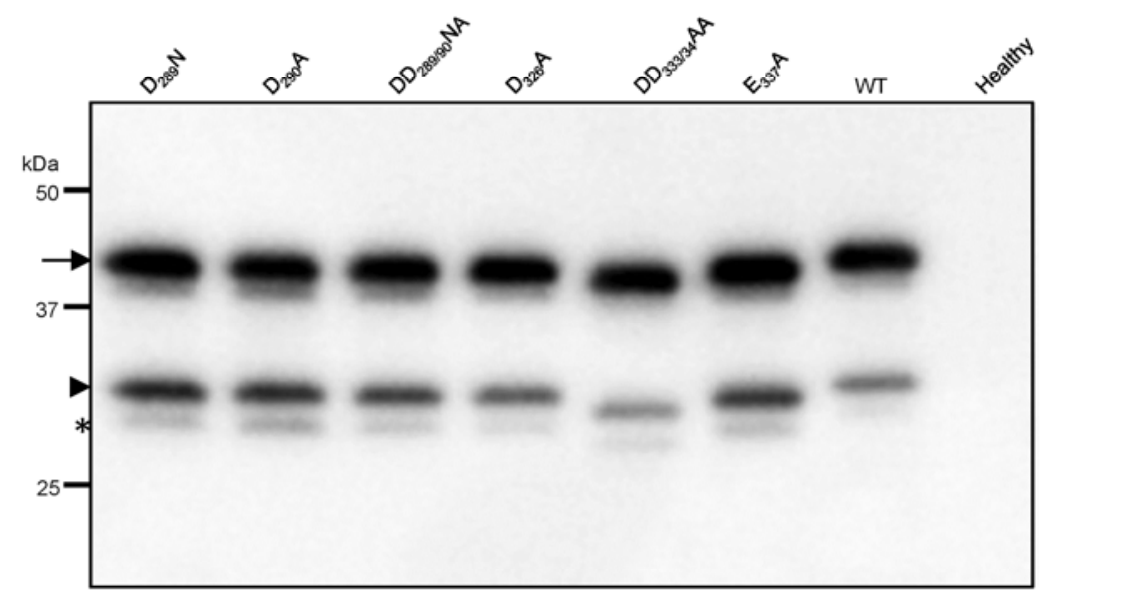

C

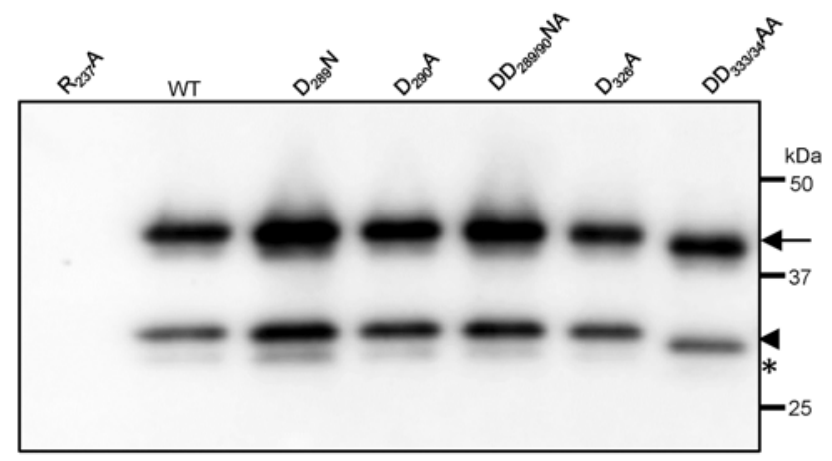

Fig. 6. Aspartic acid residues at the C-terminus of coat protein (CP) are dispensable for virion assembly of Wheat streak mosaic virus (WSMV). A, Electron micrographs of partially purified virions of WSMV aspartic acid mutants. Virions were partially purified from systemically infected wheat leaves at 18 days postinoculation. Bars represent $500 \mathrm{~nm}$. B, Western blot analysis of partially purified virions from wheat leaves infected with aspartic acid mutants as indicated. C, Western blot analysis of partially purified virions from agroinfiltrated Nicotiana benthamiana leaves at 7 days postagroinfiltration. Note that all WSMV CP aspartic acid mutants accumulated encapsidated CP equally or more than the wild-type virus in a movement-independent virion assembly assay in agroinfiltrated $N$. benthamiana leaves. The full-length 45-kDa and truncated 31- and 29-kDa CP bands are indicated with arrows, arrow heads, and asterisks, respectively. The protein size markers used in sodium dodecyl sulfate-polyacrylamide gel electrophoresis in B and $\mathrm{C}$ are indicated on the left and right, respectively. 
and cell-to-cell movement. Moreover, the WSMV CP is not required for replication (Tatineni et al. 2013), and it has not been demonstrated to have host RNA silencing suppressor activity (Young et al. 2012). Hence, it is unlikely that mild symptom phenotype of aspartic acid mutants is due to defects in virus replication or suppression of host defense mechanisms.

The aspartic acid residues at positions 289, 290, and 326 in the $\mathrm{CP}$ are required for efficient establishment of systemic infection of WSMV in wheat. It is not clear why mutation of these amino acid residues resulted in a drastic shift in symptom induction in wheat. Perhaps the C-terminus of $\mathrm{CP}$ is a dedicated cell-to-cell movement determinant of WSMV and mutation of aspartic acid residues may have affected the efficiency of cell-to-cell movement, thus causing a delay in the onset of systemic infection. The increased symptom severity phenotype of aspartic acid mutants at 15 dpi is also corroborated with a substantial increase in the accumulation of $\mathrm{CP}$ and genomic RNAs as compared with $7 \mathrm{dpi}$. At $15 \mathrm{dpi}$, mutants $\mathrm{D}_{290} \mathrm{~A}, \mathrm{DD}_{289 / 290} \mathrm{NA}$, and $\mathrm{D}_{326} \mathrm{~A}$ elicited severe symptoms similar to wild-type virus with only 31 to $46 \%$ of genomic RNA accumulation of the wild-type virus. These data suggest that there is no linear relation between virus concentration and severity of symptoms, as has been observed in other virus-host combinations (Kassanis and Bastow 1971; Técsi et al. 1994).

The C-terminal region of TEV $\mathrm{CP}$ is required for longdistance transport with little effect on cell-to-cell movement (Dolja et al. 1995). In contrast, aspartic acid residues at positions 289, 290, and 326 at the C-terminal region of WSMV CP are required for efficient cell-to-cell movement with little or no effect on long-distance transport in wheat. Efficient systemic infection, though delayed, by aspartic acid mutants, suggests that these amino acids have little or no role in long-distance movement of WSMV in wheat. The delayed onset of systemic infection by aspartic acid mutants might be due to longer periods required for the virus to come across the vascular system due to defective cell-to-cell movement. Cell-to-cell movement of TEV is likely facilitated in the form of virions (Dolja et al. 1994, 1995), and virion formation is a minimal requirement for cell-tocell movement of WSMV (Tatineni et al. 2013). It is possible that inefficient cell-to-cell movement of aspartic acid mutants in wheat could be due to their defects in virion formation. However, two lines of evidence, virions in systemically infected wheat and movement-independent virion formation in $N$. benthamiana, suggest that aspartic acid mutants are not defective in virion formation. Our data suggest that aspartic acid residues at positions 289, 290, and 326 have a role in cell-to-cell movement of WSMV in wheat independent of virion formation.

The aspartic acid mutants elicited two symptom phenotypes in maize, with residues at positions 216, 333, and 334 being dispensable for systemic infection and residues at positions 289, 290, and 326 being required for systemic infection. Mutants $\mathrm{D}_{290} \mathrm{~A}$ and $\mathrm{DD}_{289 / 290} \mathrm{NA}$ failed to infect maize, while $\mathrm{D}_{289} \mathrm{~A}$, $\mathrm{D}_{289} \mathrm{~N}$, and $\mathrm{D}_{326} \mathrm{~A}$ infected poorly, with mild and delayed symptoms, suggesting that aspartic acid residues at positions 289, 290, and 326 have an important role in interactions with maize proteins. It is possible that failure of aspartic acid mutants to infect maize is due to their defects in one or both cell-to-cell or long-distance movement. Aspartic acid mutants that failed to infect or poorly infected maize formed smaller sized local foci as compared with wild-type virus. Mutants $\mathrm{D}_{290} \mathrm{~A}$ and $\mathrm{DD}_{289 / 290} \mathrm{NA}$ formed larger local foci as compared with mutant $\mathrm{D}_{326} \mathrm{~A}$ but failed to infect maize systemically, suggesting that failure to infect maize by aspartic acid mutants is not exclusively due to defects in cell-to-cell movement.

GFP-tagged $\mathrm{D}_{289} \mathrm{~N}$ and $\mathrm{D}_{326} \mathrm{~A}$ mutants produced a few small fluorescent foci along the veins in upper noninoculated leaves of maize at 21 dpi, suggesting that these mutants are defective in either entering into or exiting from the vascular system. Failure to ingress by mutants $\mathrm{D}_{290} \mathrm{~A}$ and $\mathrm{DD}_{289 / 290} \mathrm{NA}$ and inefficient ingress by mutants $\mathrm{D}_{289} \mathrm{~N}$ and $\mathrm{D}_{326} \mathrm{~A}$ into the vascular system of maize was correlated with failure to infect and inefficient infection of maize, respectively. These data revealed that mutants $\mathrm{D}_{290} \mathrm{~A}$ and $\mathrm{DD}_{289 / 290} \mathrm{NA}$ are defective in loading the virus into the vascular system, thus failing to infect maize systemically. Though it is not known for WSMV CP, the Nand $\mathrm{C}$-terminal amino acids in potyviral $\mathrm{CP}$ are exposed on the virion surface (Allison et al. 1985; Shukla et al. 1988). It is possible that the $\mathrm{N}$ - and $\mathrm{C}$-terminal amino acids are potential targets for interactions with host factors, and the aspartic acid residues at positions 289, 290, and 326 might be such targets. Our data also suggest that aspartic acid residues at positions 289, 290, and 326 interacted differently with maize and wheat proteins, thus causing differential infection in these two hosts. The requirement of the N-terminal region for differential infection of maize by WSMV isolates (Tatineni et al. 2011b) and the C-terminal region for virus entry into the vascular system of maize (present study) suggest that the $\mathrm{N}$ - and C-terminal regions of $\mathrm{CP}$ may be involved in interactions with the host proteins for a successful invasion of hosts by WSMV. Viral determinants for host-specific infections of members of the Potyvirus genus have been studied widely, and P1, P3, 6K2, NIa-VPg, NIa-Pro, and CP have been reported to be involved in differential infection of certain hosts (Carbonell et al. 2013; Chen et al. 2008; Decroocq et al. 2009; Rajamäki and Valkonen 1999; Salvador et al. 2008; Schaad et al. 1997). The CP of tobamovirus also functions in host-specific determinant of longdistance transport and the production of Tobacco mosaic virus $\mathrm{CP}$ was implicated in symptom development (Dawson et al. 1988; Hilf and Dawson 1993).

In contrast to aspartic acid residues at positions 289, 290, and 326, mutation of aspartic acid residues at positions 216, 333 , and 334 has no measurable effect on cell-to-cell and longdistance transport, symptom induction, and ability to infect maize. However, these mutants accumulated genomic RNAs at slightly lower levels than the wild-type virus, especially during the early stages of infection. These data suggest that amino acids at positions 216, 333, and 334 provide some important functions enhancing viral fitness, particularly during the early stages of infection.

Cell-to-cell and long-distance movement of eudicotinfecting viruses, including members of the family Potyviridae has been studied widely (Benitez-Alfonso et al. 2010; Carrington et al. 1996; Harries et al. 2010; Lucas 2006), and several viral proteins have been implicated in long-distance movement of viruses (Ding et al. 1995; Prokhnevsky et al. 2002; Ryabov et al. 1999; Schaad et al. 1997). In contrast, longdistance movement of monocot-infecting plant viruses is poorly understood. Here, we provide evidence that aspartic acid residues at positions 289, 290, and 326 at the C-terminus of CP extended WSMV host range through differential long-distance transport. These amino acids play a critical role in long-distance transport of WSMV in maize with little or no effect in wheat. Our results provide evidence that the C-terminus of WSMV $\mathrm{CP}$ is involved in extension of virus host range by specifically allowing the virus into the vascular system of maize. Further studies on the requirement of host proteins and their interactions with CP would help decipher the roles of host proteins in WSMV host range and long-distance transport.

\section{MATERIALS AND METHODS}

\section{Generation of mutants.}

Infectious cDNA clones of WSMV-Sidney 81, pSP6-WSMVS81 (Choi et al. 1999), pSP6-WSMV-S81-GFP-6K1/CI(7aa), 
and pCAM-WSMV-S81-GFP-6K1/CI(7aa) (Tatineni et al. 2011a) were used as base clones to introduce mutations at the C-terminal region of CP. Mutations were introduced into oligonucleotides, and overlap extension PCR was performed (Ho et al. 1989) with oligonucleotides W-3 and W-89 (Tatineni et al. 2011b). The PCR products were ligated into pSP6-WSMV-S81 or pSP6-WSMV-S81-GFP-6K1/CI(7aa) between BstEII (nt 6,319) and NotI (at the $3^{\prime}$ end) restriction endonuclease sites as described previously (Tatineni et al. 2011b).

A PstI-NotI restriction fragment (nt 4816-3' end) from pSP6WSMV-S81 or pSP6-WSMV-S81-GFP-6K1/CI(7aa) constructs harboring aspartic acid mutations in the $\mathrm{CP}$ was ligated into similarly digested pCAM-WSMV-S81-GFP-6K1/CI(7aa) (Tatineni et al. 2011a). PCR, overlap extension PCR, and ligations and transformations were performed using standard molecular biology methods as described by Sambrook and Russell (2001). Escherichia coli JM109 was used to transform cDNA clones of WSMV, and plasmid DNA was prepared from an overnight-grown 40-ml culture using the Bio-Rad plasmid midiprep kit (Bio-Rad, Hercules, CA, U.S.A.).

The presence of introduced mutations in cDNA clones was confirmed by nucleotide sequencing. Three independent clones per mutant were used in phenotypic studies in two to three experiments and the results of one independent clone per mutant were presented.

\section{Inoculation of wheat seedlings with in vitro transcripts.}

In vitro transcripts were prepared from $1.0 \mu \mathrm{g}$ of NotI- or SpeI-linearized plasmid DNA in $40-\mu l$ reactions as described by Tatineni and associates (2011a). An equal volume of $2 \%$ sodium pyrophosphate, $\mathrm{pH}$ 9.0, containing $1.0 \%$ baked Celite was added to freshly prepared in vitro transcripts and was inoculated to wheat seedlings at the single-leaf stage using a gloved finger. Wheat seedlings were washed $5 \mathrm{~min}$ after inoculation with distilled water and were incubated in a greenhouse at 20 to $27^{\circ} \mathrm{C}$ or in a growth chamber at $24^{\circ} \mathrm{C}$ maximum and $20^{\circ} \mathrm{C}$ minimum temperature with a 14 -h photoperiod for symptom development. Total RNA and proteins were extracted from 9- and 15-dpi wheat leaves as described by Tatineni and associates $(2010,2011 \mathrm{a})$.

\section{Inoculation of SDp2 maize.}

Wheat leaves at $18 \mathrm{dpi}$ were used to prepare crude sap at a 1:10 dilution in $20 \mathrm{mM}$ sodium phosphate buffer, $\mathrm{pH} 7.0$, and the sap was used to inoculate maize inbred line SDp2 at the two- to three-leaf stage. Inoculated SDp2 maize seedlings were incubated in a growth chamber at $24^{\circ} \mathrm{C}$ maximum and $20^{\circ} \mathrm{C}$ minimum temperature with a 14 -h photoperiod. Symptom development on maize was observed from 12 dpi onwards, and symptoms were photographed at 12 and $18 \mathrm{dpi}$.

\section{Examining virus movement.}

Wheat and SDp2 maize seedlings were inoculated with in vitro transcripts of GFP-tagged viruses and crude sap at a 1:10 (wt/vol) dilution from 18-dpi wheat leaves infected with GFPtagged viruses, respectively. Cell-to-cell movement was observed by examining inoculated leaves for the development of infection foci under a Zeiss Stereo Discovery V12 fluorescence microscope (Carl Zeiss MicroImaging, Inc., New York), using a GFP narrow band filter. The GFP fluorescence pictures were taken using an AxioCam MRc5 camera attached to a V12 fluorescence microscope. The foci sizes were estimated by measuring the total area of each focus by a program provided with the AxioCam MRc5 camera. The long-distance movement of viruses was examined in upper noninoculated leaves by observing the presence of GFP fluorescence.
Analysis of accumulation of WSMV CP.

Total proteins, extracted from 9- and 15-dpi leaves, and partially purified virions (described below) were separated through 4 to $20 \%$ sodium dodecyl sulfate-polyacrylamide gel electrophoresis (SDS-PAGE) (Invitrogen, Carlsbad, CA, U.S.A.), followed by a transfer onto a polyvinylidene difluoride (PVDF) membrane using an iBlot apparatus (Invitrogen). The blots were developed using a 1:15,000 dilution of anti-WSMV serum as a primary antibody and horseradish peroxidase-labeled goat antirabbit immunoglobulin $\mathrm{G}$ (at 1:50,000) as a secondary antibody. The PVDF membranes were developed using Immobilon Western blot substrate (Millipore, Billerica, MA, U.S.A.), and images of immuno-reactive protein bands were captured using the Molecular Imager ChemiDoc XRS+ with Image Lab Software system (Bio-Rad, Hercules, CA, U.S.A.).

\section{Quantification of genomic RNA copies.}

One microgram of total RNA from 9- and 15-dpi infected plants was used to synthesize the first-strand cDNA, using random primers. One microliter of 1:10-diluted first-strand cDNA reaction was used for real-time PCR, using primers and probe as described by Tatineni and associates (2010).

\section{Virus purification and electron microscopy of virions.}

Virions were partially purified from 4 to $6 \mathrm{~g}$ of 18-dpi wheat tissue or $7 \mathrm{~g}$ of agroinfiltrated $N$. benthamiana leaves as described by Tatineni and associates (2009). Briefly, frozen infected tissue was ground in $0.1 \mathrm{M}$ sodium citrate buffer (SCB), pH 6.5, containing $0.1 \% \beta$-mercaptoethanol $(3 \mathrm{ml}$ per gram of tissue), using an electric blender (for wheat tissue) or in a mortar and pestle (for $N$. benthamiana tissue). The extract was filtered through four layers of muslin cloth and clarified at $7,700 \times g$ for $10 \mathrm{~min}$. The supernatant was treated with $2 \%$ Triton-X 100 at $4^{\circ} \mathrm{C}$ for 10 to $15 \mathrm{~min}$ and was layered on $5 \mathrm{ml}$ of $20 \%$ sucrose (wt/vol) in SCB. The virus particles were concentrated by centrifugation at $118,000 \times g$ for $1.5 \mathrm{~h}$ in a Beckman 50.2 Ti rotor. The virus pellet was suspended in $270 \mu \mathrm{l}$ of $40 \mathrm{mM}$ sodium phosphate buffer, $\mathrm{pH} 7.0$, plus $5 \%$ sucrose overnight at $4{ }^{\circ} \mathrm{C}$. Purified virus was mixed by pipetting up and down several times and was clarified at $3,000 \times g$ for $5 \mathrm{~min}$ at $4^{\circ} \mathrm{C}$. Twenty microliters of purified virion was used for electron microscopy grid preparation. Virions of wild-type and mutant viruses were observed under a Hitachi H-7500 transmission electron microscope. Purified virions were mixed with equal volumes of $2 \times$ sample buffer ( $100 \mathrm{mM}$ Tris-Cl, $\mathrm{pH} 6.8$, $4 \%$ SDS, $20 \%$ glycerol, 5\% $\beta$-mercaptoethanol and $0.02 \%$ bromophenol blue) and were incubated in a boiling water bath for $3 \mathrm{~min}$, and $20 \mu \mathrm{l}$ were used for SDS-PAGE, followed by immunoblot hybridization as described above.

\section{ACKNOWLEDGMENTS}

We thank S. N. Wegulo for editorial comments and J. Horrell and M. Bartels for their technical assistance. Mention of trade names or commercial products in this publication is solely for the purpose of providing specific information and does not imply recommendation or endorsement by the U.S. Department of Agriculture.

\section{LITERATURE CITED}

Allison, R. F., Dougherty, W. G., Parks, T. D., Willis, L., Johnston, R. F., Kelly, M., and Armstrong, F. B. 1985. Biochemical analysis of the capsid protein gene and capsid protein of Tobacco etch virus: N-terminal amino acids located on the virion's surface. Virology 147:309-316.

Alzhanova, D. V., Napuli, A. J., Creamer, R., and Dolja, V. V. 2001. Cellto-cell movement and assembly of a plant closterovirus: Roles for the capsid proteins and Hsp70 homolog. EMBO (Eur. Mol. Biol. Organ.) J. 20:6997-7007.

Anandalakshmi, R., Pruss, G. J., Ge, X., Marathe, R., Mallory, A. C., 
Smith, T. H., and Vance, V. H. 1998. A viral suppressor of gene silencing in plants. Proc. Natl. Acad. Sci. U.S.A. 95:13079-13084.

Atreya, C. D., and Pirone, T. P. 1993. Mutational analysis of the helper component-proteinase gene of a potyvirus: Effects of amino acid substitutions, deletions, and gene replacement on virulence and aphid transmissibility. Proc. Natl. Acad. Sci. U.S.A. 90:11919-11923.

Benitez-Alfonso, Y., Faulkner, C., Ritzenthaler, C., and Maule, A. J. 2010. Plasmodesmata: Gateways to local and systemic virus infection. Mol. Plant-Microbe Interact. 23:1403-1412.

Bol, J. F. 2005. Replication of Alfamo- and Ilarviruses: Role of the coat protein. Annu. Rev. Phytopathol. 43:39-62.

Brakke, M. K. 1987. Virus disease in wheat. Pages 585-603 in: Wheat and Wheat Improvement. 2nd ed. E. G. Heyne, ed. American Society of Agronomy, Crop Science Society of America, Soil Science Society of America, Madison, WI, U.S.A.

Brakke, M. K., Skopp, R. N., and Lane, L. C. 1990. Degradation of Wheat streak mosaic virus capsid protein during leaf senescence. Phytopathology 80:1401-1405.

Callaway, A., Giesman-Cookmeyer, D., Gillock, E. T., Sit, T. L., and Lommel, S. A. 2001. The multifunctional capsid protein of plant RNA viruses. Annu. Rev. Phytopathol. 39:419-460.

Carbonell, A., Maliogka, V. I., Pérez, J. D. J., Salvador, B., San León, D., García, J. A., and Simón-Mateo, C. 2013. Diverse amino acid changes at specific positions in the $\mathrm{N}$-terminal region of the coat protein allow Plum pox virus to adapt to new hosts. Mol. Plant-Microbe Interact. 26:1211-1224.

Carrington, J. C., Kasschau, K. D., Mahajan, S. K., and Schaad, M. C. 1996. Cell-to-cell and long-distance transport of viruses in plants. Plant Cell 8:1669-1681.

Carrington, J. C., Jensen, P. E., and Schaad, M. C. 1998. Genetic evidence for an essential role for potyvirus CI protein in cell-to-cell movement. Plant J 14:393-400.

Chen, K.-C., Chiang, C.-H., Raja, J. A. J., Liu, F.-L., Tai, C.-H., and Yeh, S.-D. 2008. A single amino acid of NIaPro of Papaya ringspot virus determines host specificity for infection of papaya. Mol. Plant-Microbe Interact. 21:1046-1057.

Choi, I.-R., French, R., Hein, G. L., and Stenger, D. C. 1999. Fully biologically active in vitro transcripts of the eriophyid mite-transmitted Wheat streak mosaic tritimovirus. Phytopathology 89:1182-1185.

Choi, I.-R., Horken, K. M., Stenger, D. C., and French, R. 2005. An internal RNA element in the P3 cistron of Wheat streak mosaic virus revealed by synonymous mutations that affect both movement and replication. J. Gen. Virol. 86:2605-2614.

Chung, B. Y. W., Miller, W. A., Atkins, J. F., and Firth, A. E. 2008. An overlapping essential gene in the Potyviridae. Proc. Natl. Acad. Sci. U.S.A. 105:5897-5902.

Cronin, S., Verchot, J., Haldeman-Cahill, R., Schaad, M., and Carrington, J. C. 1995. Long-distance movement factor: a transport function of the potyvirus helper component proteinase. Plant Cell 7:549-559.

Culver, J. N. 2002. Tobacco mosaic virus assembly and disassembly: Determinants in pathogenicity and resistance. Annu. Rev. Phytopathol. 40:287-308

Dawson, W. O., Bubrick, P., and Grantham, G. L. 1988. Modification of the Tobacco mosaic virus coat protein gene affecting replication, movement and symptomatology. Phytopathology 78:783-89.

Decroocq, V., Salvador, B., Sicard, O., Glasa, M., Cosson, P., SvanellaDumas, L., Revers, F., García, J. A., and Candresse, T. 2009. The determinant of potyvirus ability to overcome the RTM resistance of Arabidopsis thaliana maps to the N-terminal region of the coat protein. Mol. Plant-Microbe Interact. 22:1302-1311.

Ding, S. W., Li, W. X., and R. H. Symon. 1995. A novel naturally occurring hybrid gene encoded by a plant RNA virus facilitates long-distance virus movement. EMBO (Eur. Mol. Biol. Organ.) J. 14:5762-5772.

Dolja, V. V., Boyko, V. P., Agranovsky, A. A., and Koonin, E. V. 1991. Phylogeny of capsid proteins of rod-shaped and filamentous RNA plant viruses: Two families with distinct patterns of sequence and probably structure conservation. Virology 184:79-86.

Dolja, V. V., Haldeman, R., Robertson, N. L., Dougherty, W. G., and Carrington, J. C. 1994. Distinct functions of capsid protein in assembly and movement of Tobacco etch Potyvirus in plants. EMBO (Eur. Mol. Biol. Organ.) J. 13:1482-1491.

Dolja, V. V., Haldeman-Cahill, R., Montgomery, A. E., Vandenbosch, K. A., and Carrington, J. C. 1995. Capsid protein determinants involved in cell-to-cell and long-distance movement of Tobacco etch potyvirus. Virology 206:1007-1016.

Dunoyer, P., Thomas, C., Harrison, S., Revers, F., and Maule, A. 2004. A cysteine-rich plant protein potentiates Potyvirus movement through an interaction with the virus genome-linked protein VPg. J. Virol. 78:2301-2309.

French, R., and Stenger, D. C. 2004. Wheat streak mosaic virus. Pages
602-604 in: Viruses and Virus Diseases of Poaceae. H. Lapierre and P. Signoret, eds. INRA Editions, Paris.

Harries, P., and Ding, B. 2011. Cellular factors in plant virus movement: At the leading edge of macromolecular trafficking in plants. Virology 411:237-243.

Harries, P. A., Schoelz, J. E., and Nelson, R. S. 2010. Intracellular transport of viruses and their components: Utilizing the cytoskeleton and membrane highways. Mol. Plant-Microbe Interact. 23:1381-1393.

Hilf, M. E., and Dawson, W. O. 1993. The tobamovirus coat protein functions as a host-specific determinant of long-distance movement. Virology 193:106-114.

Hipper, C., Brault, V., Ziegler-Graff, V., and Revers, F. 2013. Viral and cellular factors involved in phloem transport of plant viruses. Frontiers in Plant Science 4:154. doi:10.3389/fpls.2013.00154. Published online.

Ho, S. N., Hunt, H. D., Horton, R. M., Pullen, J. K., and Pease, L. R. 1989. Site-directed mutagenesis by overlap extension using polymerase chain reaction. Gene 77:51-59.

Hofius, D., Maier, A. T., Dietrich, C., Jungkunz, I., Bornke, F., Maiss, E. and Sonnewald, U. 2007. Capsid protein-mediated recruitment of host DnaJ-like proteins is required for Potato virus $\mathrm{Y}$ infection in tobacco plants. J Virol 81:11870-11880.

Kassanis, B., and Bastow, C. 1971. The relative concentration of infective intact virus and RNA of four strains of tobacco mosaic virus as influenced by temperature. J. Gen. Virol. 11:157-170.

Kasschau, K. D., and Carrington, J. C. 1998. A counterdefensive strategy of plant viruses: Suppression of posttranscriptional gene silencing. Cell 95:461-470.

Kasschau, K. D., Cronin, S., and Carrington, J. C. 1997. Genome amplification and long-distance movement functions associated with the central domain of tobacco etch potyvirus helper component-proteinase. Virology 228:251-262.

Kawakami, S., Watanabe, Y., and Beachy, R. N. 2004. Tobacco mosaic virus infection spreads cell to cell as intact replication complex. Proc. Natl. Acad. Sci. U.S.A. 101:6291-6296.

Lucas, W. J. 2006. Plant viral movement protein: Agents for cell-to-cell trafficking of viral genomes. Virology 344:169-184.

Lucas, W. J., Ham, L. K., and Kim, J. Y. 2009. Plasmodesmata-bridging the gap between neighboring plant cells. Trends Cell Biol. 19:495-503.

Maule, A. J. 2008. Plasmodesmata: Structure, function and biogenesis. Curr. Opin. Plant Biol. 11:680-686.

Nelson, R.S., and Citovsky, V. 2005. Plant viruses: Invaders of cells and pirates of cellular pathways. Plant Physiol. 138:1809-1814.

Park, S. H., Sit, T. L., Kim, K. H., and Lommel, S. A. 2012. The Red clover necrotic mosaic virus capsid protein N-terminal lysine-rich motif is a determinant of symptomatology and virion accumulation. Mol. Plant Pathol. 13:744-754.

Pouwels, J., van der Velden, T., Willemse, J., Borst, J. W., van Lent, J., Bisseling, T., and Wellink, J. 2004. Studies on the origin and structure of tubules made by the movement protein of Cowpea mosaic virus. J. Gen Virol. 85:3787-3796.

Prokhnevsky, A. I., Peremyslov, V. V., Napuli, A. J., and Dolja, V. V. 2002. Interactions between long-distance transport factor and HSP70-related movement protein of Beet yellows virus. J. Virol. 76:11003-11011.

Qu, F., and Morris, T. J. 2002. Efficient infection of Nicotiana benthamiana by Tomato bushy stunt virus is facilitated by the coat protein and maintained by p19 through suppression of gene silencing. Mol. PlantMicrobe Interact. 15:193-202.

Qu, F., Ren, T., and Morris, T. J. 2003. The coat protein of turnip crinkle virus suppresses posttranscriptional gene silencing at an early initiation step. J. Virol. 77:511-522.

Rajamäki, M.-L., and Valkonen, J. P. T. 1999. The 6K2 protein and the VPg of Potato virus A are determinants of systemic infection in Nicandra physaloides. Mol. Plant-Microbe Interact. 12:1074-1081.

Rao, A. L. N., and Grantham, G. L. 1996. Molecular studies on Bromovirus capsid protein II. Functional analysis of the amino-terminal arginine-rich motif and its role in encapsidation, movement, and pathology. Virology 226:294-305.

Roberts, I. M., Wang, D., Findlay, K., and Maule, A. J. 1998. Ultrastructural and temporal observations of the potyvirus cylindrical inclusions (CIs) show that the CI protein acts transiently in aiding virus movement. Virology 245:173-181.

Rojas, M. R., Zerbini, F. M., Allison, R. F., Gilbertson, R. L., and Lucas, W. J. 1997. Capsid protein and helper component-proteinase function as Potyvirus cell-to-cell movement proteins. Virology 237:283-295.

Ryabov, E. V., Robinson, D. J., and Taliansky, M. E. 1999. A plant virusencoded protein facilitates long-distance movement of heterologous viral RNA. Proc. Natl. Acad. Sci. U.S.A. 96:1212-1217.

Salvador, B., Delgadillo, M. O., Sáenz, P., García, J. A., and Simón-Mateo, C. 2008. Identification of Plum pox virus pathogenicity determinants in herbaceous and woody hosts. Mol. Plant-Microbe Interact. 21:20-29. 
Sambrook, J., and Russell, D. 2001. Molecular Cloning: A Laboratory manual. 3rd Edition, Cold Spring Harbor Laboratory Press. Cold Spring Harbor, NY, U.S.A.

Schaad, M. C., Lellis, A. D., and Carrington, J. C. 1997. VPg of tobacco etch potyvirus is a host genotype-specific determinant for long-distance movement. J. Virol. 71:8624-8631.

Scholthof, H. B. 2005. Plant virus transport: Motions of functional equivalence. Trends Plant Sci. 10:376-382.

Shukla, D. D., Strike, P. M., Tracy, S. L., Gough, K. H., and Ward, C. W. 1988. The $\mathrm{N}$ - and $\mathrm{C}$ termini of the coat proteins of potyviruses are surface-located and the $\mathrm{N}$-terminus contains the major virus-specific epitopes. J. Gen. Virol. 69:1497-1508.

Slykhuis, J. T. 1955. Aceria tulipae Keifer (Acarina: Eriophyidae) in relation to spread of wheat streak mosaic virus. Phytopathology 45:116128.

Soosaar, J. L. M., Burch-Smith, T. M., and Dinesh-Kumar, S. 2005. Mechanisms of plant resistance to viruses. Nat. Rev. Microbiol. 3:789-798.

Stenger, D. C., Hall, J. S., Choi, I. R., and French, R. 1998. Phylogenetic relationships within the family Potyviridae: Wheat streak mosaic virus and Brome streak mosaic virus are not members of the genus Rymovirus. Phytopathology 88:782-787.

Stenger, D. C., French, R., and Gildow, F. E. 2005a. Complete deletion of Wheat streak mosaic virus HC-Pro: A null mutant is viable for systemic infection. J. Virol. 79:12077-12080.

Stenger, D. C., Hein, G. L., Gildow, F. E., Horken, K. M., and French, R. 2005b. Plant virus HC-Pro is a determinant of eriophyid mite transmission. J. Virol. 79:9054-9061.

Stenger, D. C., Hein, G. L., and French, R. 2006. Nested deletion analysis of Wheat streak mosaic virus HC-Pro: Mapping of domains affecting polyprotein processing and eriophyid mite transmission. Virology 350:465-474.

Tatineni, S., Ziems, A. D., Wegulo, S. N., and French, R. 2009. Triticum mosaic virus: A distinct member of the Family Potyviridae with an unusually long leader sequence. Phytopathology 99:943-950.

Tatineni, S., Graybosch, R. A., Hein, G. L., Wegulo, S. N., and French, R. 2010. Wheat cultivar-specific disease synergism and alteration of virus accumulation during co-infection with Wheat streak mosaic virus and Triticum mosaic virus. Phytopathology 100:230-238.

Tatineni, S., McMechan, J. A., Hein, G. L., and French R. 2011a. Efficient and stable expression of GFP through Wheat streak mosaic virus-based vectors in cereal hosts using a range of cleavage sites: Formation of dense fluorescent aggregates for sensitive virus tracking. Virology 410:268-281.
Tatineni, S., Van Winkle, D. H., and French, R. 2011b. The N-termina region of Wheat streak mosaic virus coat protein is a host- and strainspecific long-distance transport factor. J. Virol. 85:1718-1731.

Tatineni, S., Qu, F., Li, R., Morris, T. J., and French, R. 2012. Triticum mosaic poacevirus enlists $\mathrm{P} 1$ rather than HC-Pro to suppress RNA silencing-mediated host defense. Virology 433:104-115.

Tatineni, S., Kovacs, F., and French, R. 2013. Wheat streak mosaic virus infects systemically despite extensive coat protein deletions: Identification of virion assembly and cell-to-cell movement determinants. J. Virol. doi:10.1128/JVI.21737-13. Published online.

Técsi, L. I., Maule, A. J., Smith, A. M., and Leegood, R. C. 1994. Complex, localized changes in $\mathrm{CO}_{2}$ assimilation and starch content associated with the susceptible interaction between cucumber mosaic virus and a cucurbit host. Plant J. 5:837-847.

Vijayapalani, P., Maeshima, M., Nagasaki-Takekuchi, N., and Miller, W. A. 2012. Interaction of the trans-frame potyvirus protein P3N-PIPO with host protein PCaP1 facilitates potyvirus movement. PLoS Pathog. 8:e1002639. Published online. doi:10.1371/journal.ppat.1002639

Voinnet, O., Pinto, Y. M., and Baulcombe, D. C. 1999. Suppression of gene silencing: A general strategy used by diverse DNA and RNA viruses of plants. Proc. Natl. Acad. Sci. U.S.A. 96:14147-14152.

Waigmann, E., Ueki, S., Trutnyeva, K., and Citovsky, V. 2004. The ins and outs of nondestructive cell-to-cell and systemic movement of plant viruses. CRC Crit. Rev. Plant Sci. 23:195-250.

Wang, H. L., Wang, Y., Giesman-Cookmeyer, D., Lommel, S. A., and Lucas, W. J. 1998. Mutations in viral movement protein alter systemic infection and identify an intercellular barrier to entry into the phloem long-distance transport system. Virology 245:75-89.

Wei, T., Zhang, C., Hong, J., Xiong, R., Kasschau, K. D., Zhou, X., Carrington, J. C., and Wang, A. 2010. Formation of complexes at plasmodesmata for potyvirus intercellular movement is mediated by the viral protein P3N-PIPO. PLoS Pathog. 6:e1000962. Published online. doi:10.1371/journal.ppat.1000962

Wen, R. H., and Hajimorad, M. R. 2010. Mutational analysis of the putative PIPO of Soybean mosaic virus suggests disruption of PIPO protein impedes movement. Virology 400:1-7.

Xoconostle-Cazares, B., Ruiz-Medrano, R., and Lucas, W. J. 2000. Proteolytic processing of $\mathrm{CmPP} 36$, a protein from the cytochrome $\mathrm{b}(5)$ reductase family, is required for entry into the phloem translocation pathway. Plant J. 24:735-747.

Young, B. A., Stenger, D. C., Qu, F., Morris, T. J., Tatineni, S., and French, R. 2012. Tritimovirus P1 functions as a suppressor of RNA silencing and an enhancer of disease symptoms. Virus Res. 163:672-677.
A corrected version of Fig. 6 with the labels of some of the images in part A changed was published online on January 10, 2014. 